\title{
Experimental and modelling study on the influence of wood type, density, water content, and temperature on wood devolatilization
}

Luo, Hao; Lu, Zhimin; Jensen, Peter Arendt; Glarborg, Peter; Lin, Weigang; Dam-Johansen, Kim; Wu, Hao

Published in:

Fuel

Link to article, DOI:

10.1016/j.fuel.2019.116410

Publication date:

2020

Document Version

Peer reviewed version

Link back to DTU Orbit

Citation (APA):

Luo, H., Lu, Z., Jensen, P. A., Glarborg, P., Lin, W., Dam-Johansen, K., \& Wu, H. (2020). Experimental and modelling study on the influence of wood type, density, water content, and temperature on wood devolatilization. Fuel, 260, [116410]. https://doi.org/10.1016/j.fuel.2019.116410

\section{General rights}

Copyright and moral rights for the publications made accessible in the public portal are retained by the authors and/or other copyright owners and it is a condition of accessing publications that users recognise and abide by the legal requirements associated with these rights.

- Users may download and print one copy of any publication from the public portal for the purpose of private study or research.

- You may not further distribute the material or use it for any profit-making activity or commercial gain

- You may freely distribute the URL identifying the publication in the public portal 


\title{
Experimental and modelling study on the influence of wood
} type, density, water content, and temperature on wood devolatilization

\author{
Hao Luo ${ }^{1}$, Zhimin $\mathrm{Lu}^{2 *}$, Peter Arendt Jensen ${ }^{1}$, Peter Glarborg ${ }^{1}$, Weigang \\ Lin $^{1}$, Kim Dam-Johansen ${ }^{1}$, Hao Wu ${ }^{1}{ }^{*}$ \\ ${ }^{1}$ Department of Chemical and Biochemical Engineering, Technical University of Denmark, 2800 \\ Kongens Lyngby, Denmark \\ ${ }^{2}$ School of Electric Power, South China University of Technology, China \\ ${ }^{*}$ Corresponding author: zhmlu@scut.edu.cn, haw@kt.dtu.dk
}

\section{Abstract}

Wood devolatilization experiments in a single particle combustor and comparison with a $1 \mathrm{D}$ devolatilization model were carried out to investigate the effects of wood particle properties and operation conditions on wood particle devolatilization time. The experiments were conducted with $3 \mathrm{~mm}$ spherical/cubic and $4 \mathrm{~mm}$ spherical particles at gas temperatures of 1200 $1450^{\circ} \mathrm{C}$ and oxygen contents of $0-4.4$ vol\%. Both experimental and modelling results showed that the devolatilization time increases linearly with particle density for raw, wetted, and torrefied wood particles. A sensitivity analysis done with the 1D devolatilization model showed that the biomass devolatilization time is sensitive to particle size, moisture content, gas temperature and particle density, and insensitive to volatiles fraction and gas velocity under the investigated experimental conditions. Using the same devolatilization kinetics, the 1D model could predict well the devolatilization time of different wood species with different particle size, density and moisture content. With this in mind, a simple correlation for devolatilization time has been developed based on the simulation data from the 1D model. The correlation uses a four-variable function with input of particle size, moisture content, gas temperature and particle density to determine the devolatilization time of biomass. Experimental devolatilization time found in literature could be predicted within $\pm 25 \%$ for large particles $(1 \mathrm{~mm}-10 \mathrm{~mm})$ under high temperature conditions $\left(1000^{\circ} \mathrm{C}-1600^{\circ} \mathrm{C}\right)$. 
Keywords: biomass, devolatilization, particle density, single particle model

\section{Introduction}

Biomass devolatilization involves chemical reactions coupled with internal and external heat and mass transfer [1-4]. Devolatilization is an important step for both ignition and burnout of biomass particles during combustion. Several experimental studies [5-9] have been done to investigate biomass devolatilization under high-temperature conditions $\left(\geq 1200^{\circ} \mathrm{C}\right)$ that are representative for pulverized biomass combustion [5,7-9]. The existing studies found that the devolatilization time of biomass particles decreases with increasing gas temperature and oxygen concentration [5], and increases with increasing particle size [5-8], moisture content [7] and density $[8,9]$. However, to the authors' knowledge, a comprehensive comparison of the influences of the different factors on devolatilization time has not been carried out under pulverized biomass combustion conditions. To support fuel selection and burner optimization in pulverized biomass-fired power plants, it is important to identity the key parameters controlling the devolatilization time of biomass particles, and to develop reliable modelling tools to describe the devolatilization process.

Detailed one-dimensional (1D) models have been developed to describe the devolatilization of single biomass particles [10-18]. The existing models have been used to study the effects of particle shape [10], moisture content [10,14], particle size [18], heat flux[17,18] on the biomass devolatilization and validated mainly by experiments under relatively low-temperature conditions $\left(T_{g}<1200^{\circ} \mathrm{C}\right)$. These models have only been validated to a limited extent under high temperature conditions $\left(\geq 1200^{\circ} \mathrm{C}\right)$ with respects to the effects of particle shape [19], particle size $[4,19,20]$. Other important factors, such as the moisture content and density of particles are rarely specifically studied by experiments and modelling. In order to develop a reliable model that is applicable in pulverized biomass combustion. Comprehensive experimental data with different particle density and particle moisture content at high-temperature are desirable to validate the model.

Beside the detailed 1D models, empirical correlations have also been developed to estimate the devolatilization time of biomass particles [7,21-25]. Most of the existing correlations primarily 
use a power law to correlate the devolatilization time with particle size with a number of fitting parameters under fluidized bed combustors with relatively low temperature $\left(<1000{ }^{\circ} \mathrm{C}\right)[21-$ 25]. Empirical correlations are rarely reported for biomass devolatilization under pulverized flame conditions. Mason et al. [7] correlated the devolatilization time as function of particle moisture content, particle size, and particle density at a temperature of $1550^{\circ} \mathrm{C}$ for 3 different woody biomass at suspension combustion conditions. However, the obtained coefficients of different woody biomass particle are significant different, and the developed correlation has only been validated with a limited number of experiments. Thus, a more generic correlation valid for different biomass properties and operation conditions is required.

The present work aims to investigate the effects of particle properties and reactor conditions on biomass devolatilization under pulverized biomass combustion conditions. Experiments with spherical and cubic wood particles having different density, size, wood type, and moisture content were carried out in a single particle combustor under different temperature and gas atmosphere conditions. A comprehensive 1D devolatilization model developed from our previous work $[4,26]$ was used to model the experiments. Finally, a simple correlation based on the 1D devolatilization model was introduced to estimate the devolatilization time of wood particles at high temperatures.

\section{Experiments}

\subsection{Single particle combustor}

A single particle combustor (SPC), designed for combustion studies of fuel particles with local conditions similar to that in pulverized fuel fired boilers was used [5]. Detailed descriptions of the reactor and experimental procedures can be found elsewhere $[5,8,9]$. In the experiments, an individual wood particle was held by a $0.3 \mathrm{~mm}$ titanium wire on a ceramic sample probe and suspended in the flue gas from hydrogen flame. The combustion process of the single wood particle was recorded by a video camera. In the present work, the devolatilization time is sum of ignition and pyrolysis time, the method to estimate the ignition and pyrolysis time can be found in our previous work [5]. The detailed image post-processing for determining the 


\subsection{Materials}

In a pulverized wood-fired power plant, particles fed to the pulverized burners are in as size range of from $10 \mu \mathrm{m}$ to $5 \mathrm{~mm}$ wood particles [27], The millimeter-size wood particles in a pulverized biomass combustor may result in unburned carbon in both bottom and fly ash, and therefore need special attention [28]. In addition, the experiments with millimeter-sized wood particles are relatively easy to be carried out. In the present study, millimeter-size wood particles have been chosen for experiments in the single particle combustor. Three types of pine, beech, and bamboo were selected as the raw material in the series I experiments. The particles used in series I experiments are all spherical and having two different sizes of $\sim 4 \mathrm{~mm}$ and $\sim 3 \mathrm{~mm}$. The proximate analysis and the inorganic composition are shown in Table 1. The mass and diameter of individual particles were measured by using a microbalance $( \pm 0.01 \mathrm{mg})$ and a caliper $( \pm 0.05$ $\mathrm{mm})$. For $\sim 4 \mathrm{~mm}$ wood particles, the measured mean particle diameters of pine, beech, and bamboo particles were $4.00 \mathrm{~mm}, 4.13 \mathrm{~mm}$ and $3.97 \mathrm{~mm}$, respectively. In the case of $\sim 3 \mathrm{~mm}$ spherical wood particles, the mean diameters were $3.12 \mathrm{~mm}$ and $3.03 \mathrm{~mm}$ of pine and beech wood, respectively. To investigate the effects of density on devolatilization time, particles with significantly different mass were selected in the experiments. The corresponding density ranges were $400-900,600-1100$, and $400-900 \mathrm{~kg} / \mathrm{m}^{3}$ for pine, beech, and bamboo, respectively. The "density" in the present work refers to "particle density on dry basis". To produce wetted wood particles with different moisture content, selected particles were submerged into deionized water. Then they were taken out and exposed to air to obtain a specified moisture content (as received based: $\sim 15.0 \%, \sim 30.0 \%, \sim 50.0 \%$ ). The actual moisture content of an individual wetted particle varies slightly $(<4 \%)$ from the averaged moisture content. 
108 experiments

\begin{tabular}{lllll}
\hline Parameter & Unit & Pine & Beech & Bamboo \\
\hline Moisture Content & $\mathrm{ar} \%$ & 6.9 & 4.9 & 5.2 \\
Ash & $\mathrm{db} \%$ & 0.2 & 0.6 & 1.9 \\
Volatiles & $\mathrm{db} \%$ & 86.6 & 83.7 & 79.0 \\
Fixed carbon & $\mathrm{db} \%$ & 13.2 & 15.7 & 19.1 \\
$\mathrm{Al}$ & $\mathrm{mg} / \mathrm{kg}, \mathrm{db}$ & 10 & $<10$ & $<10$ \\
$\mathrm{Fe}$ & $\mathrm{mg} / \mathrm{kg}, \mathrm{db}$ & 42 & 29 & 38 \\
$\mathrm{P}$ & $\mathrm{mg} / \mathrm{kg}, \mathrm{db}$ & 82 & 70 & 82 \\
$\mathrm{Ti}$ & $\mathrm{mg} / \mathrm{kg}, \mathrm{db}$ & $<3$ & $<3$ & $<3$ \\
$\mathrm{~K}$ & $\mathrm{mg} / \mathrm{kg}, \mathrm{db}$ & 150 & 1700 & 8700 \\
$\mathrm{Na}$ & $\mathrm{mg} / \mathrm{kg}, \mathrm{db}$ & 20 & $<10$ & 22 \\
$\mathrm{Ca}$ & $\mathrm{mg} / \mathrm{kg}, \mathrm{db}$ & 530 & 2000 & $<200$ \\
$\mathrm{Mg}$ & $\mathrm{mg} / \mathrm{kg}, \mathrm{db}$ & 75 & 290 & 490 \\
$\mathrm{Si}$ & $\mathrm{mg} / \mathrm{kg}, \mathrm{db}$ & $<100$ & $<100$ & 290 \\
\hline
\end{tabular}

109 In series II experiments, particles ( $\sim 3 \mathrm{~mm}$ cubic) from five wood types with and without

110 torrefaction pretreatment were used. The torrefaction was made using a 3-zone electrically

111 heated tube oven [8]. After the oven was stabilized at $290^{\circ} \mathrm{C}$, an $\mathrm{Al}_{2} \mathrm{O}_{3}$ boat $(120 \times 30 \times 17 \mathrm{~mm}$,

112 without a lid) carrying 30 wood particles (6 samples of each wood species) was inserted into

113 the center of the oven under a $\mathrm{N}_{2}$ flow of $15 \mathrm{STP} 1 /$ min for 1 hour. The proximate analysis and

114 other properties of particles with and without torrefaction are shown in Table 2. The wood

115 particles have small differences and variations in length, between 2.78 and $3.03 \mathrm{~mm}$ with a

116 maximum standard derivation of $0.03 \mathrm{~mm}$. The apparent wood particle densities were

117 calculated to vary from 184 to $698 \mathrm{~kg} / \mathrm{m}^{3}$ based on the weighted mass of particles. 
Table 2. Properties of $\sim 3 \mathrm{~mm}$ cubic wood particles with and without torrefaction

\begin{tabular}{lllllll}
\hline Parameter & Unit & Balsa & Paulownia & Pine & Beech & Sapele \\
\hline \multicolumn{2}{l}{ Wood without torrefaction } & & & & & \\
Moisture & $\mathrm{ar} \%$ & 5.0 & 4.9 & 6.4 & 6.3 & 7.7 \\
Ash & $\mathrm{db} \%$ & 2.1 & 0.6 & 0.1 & 0.5 & 0.9 \\
Volatiles & $\mathrm{db} \%$ & 81.1 & 80.2 & 82.1 & 80.4 & 74.3 \\
Fixed carbon & $\mathrm{db} \%$ & 16.8 & 19.1 & 17.8 & 19.1 & 24.8 \\
$\mathrm{~K}$ & $\mathrm{mg} / \mathrm{kg}, \mathrm{db}$ & 5522 & 2122 & 85 & 1060 & 65 \\
$\mathrm{Na}$ & $\mathrm{mg} / \mathrm{kg}, \mathrm{db}$ & 189 & 30 & 9 & 64 & 64 \\
Ca & $\mathrm{mg} / \mathrm{kg}, \mathrm{db}$ & 2318 & 467 & 250 & 1032 & 3399 \\
Mg & $\mathrm{mg} / \mathrm{kg}, \mathrm{db}$ & 644 & 27 & 61 & 203 & 457 \\
Si & $\mathrm{mg} / \mathrm{kg}, \mathrm{db}$ & 737 & 526 & 321 & 427 & 758 \\
Mass & $\mathrm{mg}$ & $6.70 \pm 0.25$ & $9.30 \pm 0.35$ & $11.70 \pm 0.10$ & $17.50 \pm 0.41$ & $19.00 \pm 0.69$ \\
Cube lengths & $\mathrm{mm}$ & $3.02 \pm 0.03$ & $3.03 \pm 0.02$ & $2.97 \pm 0.03$ & $2.96 \pm 0.03$ & $3.01 \pm 0.03$ \\
Apparent density & $\mathrm{kg} / \mathrm{m}^{3}$ & 243 & 335 & 446 & 673 & 698 \\
\hline Wood with torrefaction & & & & & \\
Moisture & $\mathrm{ar} \%$ & 3.0 & 2.6 & 3.0 & 3.8 & 3.9 \\
Ash & $\mathrm{db} \%$ & 3.0 & 0.8 & 0.1 & 0.8 & 1.1 \\
Voltailes & $\mathrm{db} \%$ & 69.0 & 76.4 & 78.5 & 73.5 & 68.6 \\
Fixed carbon & $\mathrm{db} \%$ & 28.0 & 22.8 & 21.4 & 25.7 & 30.3 \\
Mass & $\mathrm{mg}$ & $4.25 \pm 0.18$ & $6.51 \pm 0.18$ & $8.26 \pm 0.21$ & $12.67 \pm 0.24$ & $14.00 \pm 0.50$ \\
Cube lengths & $\mathrm{mm}$ & $2.85 \pm 0.12$ & $2.94 \pm 0.06$ & $2.77 \pm 0.14$ & $2.78 \pm 0.14$ & $2.89 \pm 0.10$ \\
Apparent density & $\mathrm{kg} / \mathrm{m}^{3}$ & 184 & 256 & 389 & 589 & 583 \\
\hline & & & & & & \\
\hline
\end{tabular}

\subsection{Operating conditions}

120 The operating conditions of experiment series I and II are shown in Table 3. Series I experiment

121 has been carried out in the single particle combustor with different temperatures of

$1221208 / 1221 / 1357 / 1400 / 1441^{\circ} \mathrm{C}$, and oxygen concentrations of $0.0 \% / 4.4 \%$, while series II

123 experiments have been carried out using a temperature of $1256^{\circ} \mathrm{C}$ and an oxygen content of

$1242.8 \%$. The extracted flue gas samples from the reactor outlet were dried and the $\mathrm{O}_{2}$

125 concentrations were measured. Based on the stoichiometry and the ideal gas assumption, the 
concentrations of $\mathrm{O}_{2}$ and $\mathrm{H}_{2} \mathrm{O}$ in the reactor were calculated as shown in Table 3. According to

127 our previous work [8], the difference between the calculated $\mathrm{O}_{2}$ concentration and the measured

128 value is small, therefore the calculated concentrations of $\mathrm{O}_{2}$ and $\mathrm{H}_{2} \mathrm{O}$ are used in the modelling.

129 The averaged gas velocity in the single particle combustor was about $1.5 \mathrm{~m} / \mathrm{s}$ as shown in Table

1303 . The wall temperature is assumed to be $200^{\circ} \mathrm{C}$ (estimated from the measured radial

131 temperature distribution of our previous work $[5,8]$ ) lower than the gas temperature in our

132 devolatilization model.

133 Table 3. Operating conditions of single particle combustor

\begin{tabular}{lllll}
\hline No. & $\begin{array}{l}\text { Measured gas } \\
\text { temperature } \\
\left({ }^{\circ} \mathrm{C}\right)\end{array}$ & $\begin{array}{l}\text { Calculated } \\
\text { gas velocity } \\
(\mathrm{m} / \mathrm{s})\end{array}$ & $\begin{array}{l}\text { Calculated } \mathrm{O}_{2} \\
\text { concentration } \\
\text { (wet basis, vol\%) }\end{array}$ & $\begin{array}{l}\text { Calculated } \mathrm{H}_{2} \mathrm{O} \\
\text { concentration } \\
\text { (wet basis, vol\%) }\end{array}$ \\
\hline Series I & & & & \\
$0 \% \mathrm{O} 2 / 1214^{\circ} \mathrm{C}$ & 1221 & 1.49 & 0.0 & 26.8 \\
$0 \% \mathrm{O} 2 / 1357^{\circ} \mathrm{C}$ & 1357 & 1.50 & 0.0 & 39.7 \\
$0 \% \mathrm{O} 2 / 1400^{\circ} \mathrm{C}$ & 1400 & 1.42 & 0.0 & 39.1 \\
$0 \% \mathrm{O} 2 / 1441{ }^{\circ} \mathrm{C}$ & 1441 & 1.40 & 0.0 & 41.8 \\
$4.4 \% \mathrm{O} 2 / 1210^{\circ} \mathrm{C}$ & 1208 & 1.43 & 4.4 & 25.7 \\
\hline Series II & & & & 27.0 \\
$2.8 \% \mathrm{O} 2 / 1256^{\circ} \mathrm{C}$ & 1256 & 1.50 & 2.8 & \\
\hline
\end{tabular}

\section{Model description}

\subsection{Model assumption}

136 The model used in the present work is originally developed by Johansen et al.[4] to study the

137 influence of intraparticle heat transport on biomass devolatilization. It is further modified by

138 including the effects of heat of devolatilization, and modifying the water drying model and the

139 devolatilization kinetics in this paper. The model includes phenomena of internal and external

140 heat transfer, water evaporation, and devolatilization kinetics. The general assumptions are

141 listed as follows:

142 (1) The model is an one-dimensional model for spherical wood particle, which neglects the

143 anisotropy of wood particles, even though the anisotropy of wood is expected to be important

144 when the thermal conductivity along and across the fiber direction of wood particles is

145 significantly different. A two- or three-dimensional model may be considered to implement the 
anisotropy of wood particle. However, 2D or 3D model will results in much more complex and computationally intensive than a 1D model [2]. Moreover, the thermal conductivity along and

148 across the fiber direction is not easily measured from experiments, while there are available and

149 validated expression of effective dry wood conductivity. Furthermore, previous studies [10-18]

150 have shown that appropriate devolatilization modelling can be obtained without consider the

151 anisotropy of the wood. Thus, the anisotropy of wood is neglected in the present model.

152 (2) No convective heat transport takes place inside the particle, only heat conduction;

153 (3) No mass transfer limitation of the released volatiles is included;

154 (4) The reactor walls contribute to the radiative heat flux between the particle external surface 155 and the environment;

156 (5) A fully devolatilized particle has a shrinkage factor of 0.2 (volume based) and the particle 157 volume shrinks linearly with the devolatilization degree.

158 (6) The devolatilization time is determined by $99 \%$ particle conversion (the amount of 159 released moisture and volatiles divided by the amount of initial moisture and volatiles inside 160 particle);

161 The assumptions above are commonly applied in the particle modelling literature $162[4,10,12,14,29]$.

\subsection{Governing equations}

The devolatilization model, which includes both internal and external heat transfer, is described as Eq. (1):

$$
C_{p} \rho_{p} \frac{\partial T(t, r)}{\partial t}=\frac{1}{r^{2}} \frac{\left(r^{2} \lambda_{e f f} \frac{\partial T(t, r)}{\partial r}\right)}{\partial r}-\frac{d X_{w}}{d t} \rho_{D B} Y_{w 0} Q_{w}-\frac{d X_{v o l}}{d t} \rho_{D B} Y_{v o l 0} Q_{p y r o}
$$

Here, $C_{p}, \rho_{p}, \lambda_{\text {eff }}$ are the specific heat capacity $(\mathrm{J} /(\mathrm{kg} \mathrm{K}))$, particle density $\left(\mathrm{kg} / \mathrm{m}^{3}\right)$, effective thermal conductivity $(\mathrm{W} /(\mathrm{m} \mathrm{K}))$ of the biomass particle at time $t$, respectively. $\rho_{D B}$ is the initial particle density $\left(\mathrm{kg} / \mathrm{m}^{3}\right)$ at $t=0 \mathrm{~s}, r$, the radial position (m), $t$, time (s), $T$, the particle temperature $(K), Y_{w 0}$ is the initial water mass fraction (dry basis), and $Y_{v o l 0}$ is the initial mass fraction of

171 volatiles (dry basis). $Q_{w}$ and $Q_{p y r o}$ are the evaporation heat and devolatilization heat $(\mathrm{J} / \mathrm{Kg})$, 
respectively. $d X_{w} / d t$ and $d X_{v o l} / d t$ are conversion rates described by a drying model and a devolatilization model.

The boundary conditions of the model include both convection and radiation heat transfer are described by Eq. (2) and Eq. (3).

$$
\begin{gathered}
\left.\frac{\partial T}{\partial r}\right|_{r=0}=0, \text { all } t \text { (2) } \\
\left.\lambda_{\text {eff }} \frac{\partial T}{\partial r}\right|_{r=R}=h_{c}\left(T_{g}-T_{s}\right)+\xi \sigma\left(T_{w}^{4}-T_{s}^{4}\right) t>0
\end{gathered}
$$

Here, $h_{c}$ is the convective heat transfer coefficient, $\mathrm{W} /\left(\mathrm{m}^{2} \mathrm{~K}\right), T_{g}, T_{w}$, and $T_{s}$ are gas, wall and particle external surface temperatures $(\mathrm{K}), \xi$ is the particle emissivity, which depends on many factors (e.g. temperature, wood type, surface structure). The typical values reported in literature are in a range of 0.7-1.0 [2]. Because of the difficulties in an accurate determination of the particle emissivity under different conditions, a fixed particle emissivity of 0.85 is selected in the 1D model. The effects of emissivity on modelling results is shown in the section of sensitivity analysis. $\sigma$ is Stenfan-Boltzmann constant $\left(5.6704 \times 10^{-8} \mathrm{~J} /\left(\mathrm{m}^{2} \mathrm{~K}^{4} \mathrm{~s}\right)\right)$.

\subsection{Physical properties}

Table 4 summarizes the physical properties used in this work. The effective heat conductivity ( $\lambda_{\text {eff }}$ ) of the biomass particle is expressed as a sum of the conduction in the solid phase $\left(\lambda_{p}\right)$, gas phase $\left(\varepsilon_{\mathrm{g}} \lambda_{\mathrm{g}}\right)$, liquid moisture $\left(\varepsilon_{\mathrm{w}} \lambda_{w}\right)$, and radiative conduction $\left(\lambda_{r}\right)$ [30]. The solid phase heat conductivity $\lambda_{p}$ is a function of volatiles conversion [4]. The conduction by radiation $\lambda_{r}$ is a function of particle pore size and particle temperature [4,30], with the particle pore diameter $\left(d_{p o r e}\right)$ assumed to vary linearly with the conversion [4]. When the moisture content is larger than $Y_{f s b}$ (fibre saturation point), the heat required for water evaporation is the heat of vaporization, $\Delta_{v a p} H$. When it is smaller than $Y_{f s b}$, the heat required is the sum of heat of vaporization and desorption of bound water [4,31]. The convective heat transfer coefficient $\left(h_{c}\right)$ of a spherical particle is determined by Ranz and Marshall equation [32]. The shrinkage factor ( $\varphi$, volume based) which is dependent of the experimental conditions and wood type as reported in previous studies $[10,16,33]$, is assumed to be 0.2 in this work. All of the thermos- 
198 physical properties described above are summarized in Table 4. The bulk gas physical

199 properties are not shown in Table 4, but given in supplementary material.

200 Table 4. A summary of physical properties used in the particle-scale models for wood devolatilization

\begin{tabular}{|c|c|c|c|c|}
\hline Parameters & Units & Description & Expressions & Ref. \\
\hline$\lambda_{B}$ & $\mathrm{~W} / \mathrm{m} / \mathrm{K}$ & Dry wood conductivity & $\begin{array}{l}0.13+3 \times 10^{-4}(\mathrm{~T}-273), \mathrm{T} \leq 1006 \mathrm{~K} \\
0.3, \mathrm{~T}>1006 \mathrm{~K}\end{array}$ & {$[4,34]$} \\
\hline$\lambda_{C}$ & $\mathrm{~W} / \mathrm{m} / \mathrm{K}$ & Char conductivity & 0.071 & {$[10,16,35,36]$} \\
\hline$\lambda_{p}$ & $\mathrm{~W} / \mathrm{m} / \mathrm{K}$ & Particle conductivity & $\lambda_{B}\left(1-X_{v o l}\right)+\lambda_{C} X_{v o l}$ & [4] \\
\hline$\lambda_{g}$ & $\mathrm{~W} / \mathrm{m} / \mathrm{K}$ & Gas conductivity & 0.0258 & {$[4,11,16,17,36,37]$} \\
\hline$\lambda_{r}$ & $\mathrm{~W} / \mathrm{m} / \mathrm{K}$ & Radiative conductivity & $\sigma d_{p o r e} T_{p}^{3} / \xi$ & {$[4,10,11]$} \\
\hline$\lambda_{w}$ & $\mathrm{~W} / \mathrm{m} / \mathrm{K}$ & Water conductivity & $\begin{array}{l}0.6065\left(-1.4845+4.1229\left(T_{p} / 298.15\right)-\right. \\
\left.1.6387\left(T_{p} / 298.15\right)^{2}\right)\end{array}$ & {$[38]$} \\
\hline$d_{\text {poreB }}$ & $\mathrm{m}$ & Wood pore diameter & $3.2 \times 10^{-6}$ & {$[4,39]$} \\
\hline$d_{\text {poreC }}$ & $\mathrm{m}$ & Char pore diameter & $1.0 \times 10^{-4}$ & {$[4,17,39]$} \\
\hline$X$ & - & Particle conversion & $\left(X_{w} Y_{w 0}+X_{v o l} Y_{v o l 0}\right) /\left(Y_{w 0}+Y_{v o l 0}\right)$ & \\
\hline$d_{\text {pore }}$ & $m$ & Particle pore diameter & $d_{\text {poreB }}(1-X)+d_{\text {porec }} X$ & {$[4,17]$} \\
\hline$\varepsilon_{g}$ & - & Particle porosity & $\begin{array}{l}1-\rho_{D B} Y_{w o}\left(1-X_{\mathrm{w}}\right) / \rho_{\text {true }} /(1-\varphi)-\rho_{D B} Y_{\text {volo }}(1- \\
\left.X_{v o l}\right) / 1000 /(1-\varphi)\end{array}$ & {$[29,33,39]$} \\
\hline$\varepsilon_{w}$ & - & Water volume fraction & $\rho_{D B} Y_{v o l o}\left(1-X_{v o l}\right) / 1000 /(1-\varphi)$ & \\
\hline$\lambda_{\text {eff }}$ & $\mathrm{W} / \mathrm{m} / \mathrm{K}$ & Effective conductivity & $\lambda_{p}+\lambda_{g a s} \varepsilon_{g}+\lambda_{r}+\lambda_{w} \varepsilon_{w}$ & {$[4,17]$} \\
\hline$\rho_{g}$ & $\mathrm{~kg} / \mathrm{m}^{3}$ & Gas density & $p M_{w} / R / T_{g}$ & {$[36]$} \\
\hline$\rho_{p}$ & $\mathrm{~kg} / \mathrm{m}^{3}$ & Particle density & $\rho_{D B}\left(1+Y_{w 0}\right)(1-X) /(1-\varphi)$ & {$[4]$} \\
\hline$C_{p c}$ & $\mathrm{~J} / \mathrm{kg} / \mathrm{K}$ & Char heat capacity & $(1000 R / 11.3)(g(380 / T)+2 g(1800 / T))$ & {$[4,10,40]$} \\
\hline$C_{p B}$ & $\mathrm{~J} / \mathrm{kg} / \mathrm{K}$ & Wood heat capacity & $\begin{array}{l}(1000 R / 7.72)(g(380 / T)+2 g(1800 / T)) \\
g(x)=x^{2} \exp (x) /(\exp (x)-1)^{2}\end{array}$ & {$[4,10,40]$} \\
\hline$C_{p w}$ & $\mathrm{~J} / \mathrm{kg} / \mathrm{K}$ & Water heat capacity & 4180 & {$[33]$} \\
\hline$C_{p}$ & $\mathrm{~J} / \mathrm{kg} / \mathrm{K}$ & Particle heat capacity & Mass averaged & \\
\hline$\Delta_{\text {vap }} H$ & $\mathrm{~J} / \mathrm{kg}$ & Heat of vaporization & $1000\left(3179-2.5 T_{p}\right)$ & [4] \\
\hline$\Delta_{d s} H$ & $\mathrm{~J} / \mathrm{kg}$ & Heat of desorption & $0.4 \Delta_{l} H\left(1-Y_{w} / Y_{f s p}\right)^{2}$ & {$[41]$} \\
\hline$Q_{w}$ & $\mathrm{~J} / \mathrm{kg}$ & Heat of water drying & $\begin{array}{l}\Delta_{v a p} H,\left(Y_{w}>Y_{f s b}\right) \\
\Delta_{v a p} H+\Delta_{d s} H\left(Y_{w} \leq Y_{f s b}\right)\end{array}$ & {$[4,41]$} \\
\hline$Y_{f s b}$ & - & Fiber saturation point & $\operatorname{Max}\left(Y_{f s b}=0.598-0.001 T_{p}, 0.2\right)$ & {$[31]$} \\
\hline$\xi$ & - & Emissivity & 0.85 & {$[4,10,17]$} \\
\hline$\sigma$ & $\mathrm{J} /\left(\mathrm{m}^{2} \mathrm{~K}^{4} \mathrm{~s}\right)$ & $\begin{array}{l}\text { Stefan-Boltzmann } \\
\text { constant }\end{array}$ & $5.6704 \times 10^{-8}$ & [42] \\
\hline$h_{c}$ & & $\begin{array}{l}\text { Convective heat } \\
\text { transfer coefficient }\end{array}$ & $\lambda_{\text {bulkg }}\left(2+0.6 \operatorname{Re}^{0.5} \operatorname{Pr}^{(1 / 3)}\right) / d_{p}$ & {$[4,32]$} \\
\hline$d_{p}$ & $\mathrm{~m}$ & Particle diameter & $d_{p 0}(1-\varphi)^{1 / 3}$ & \\
\hline$\varphi$ & & Particle shrinkage & $0.2 X$ & {$[13]$} \\
\hline
\end{tabular}




\subsection{Drying and devolatilization models}

202

204

205

206

207

208

209

210

211

212

213

214

215

216

217

The drying process is described by a first order kinetic model as shown in Eq. (4) [33]:

$$
\frac{d X_{w}}{d t}=k_{w}\left(1-X_{w}\right)
$$

The rate constant $k_{w}$ follows an Arrhenius expression. The kinetic data are shown in Table 5.

Following Johansen et al. [4], the net devolatilization rate is described by Eq. (5) and Eq. (6)

$$
\begin{aligned}
& \frac{d X_{v o l}}{d t}=k_{v o l}\left(1-X_{v o l}\right) \\
& k_{p}=k_{v}+\min \left(k_{t}, k_{t v}\right)
\end{aligned}
$$

$k_{v}, k_{t}$, and $k_{t v}$ follows the Arrhenius expression. They are the rate constant of wood to volatiles by primary devolatilization, wood to tar by primary devolatilization, and tar to volatiles by secondary devolatilization, respectively. The net devolatilization rate constant is lumped as $k_{p}$ as defined in Johansen et al. [4]. The kinetic data are derived by Wagenaar et al. [43] and have been widely used to simulate both small and large wood particles [4,10,26,44]. The kinetic parameters are listed in Table 5. Different values of reaction enthalpy, varying from 200 to $600 \mathrm{~kJ} / \mathrm{kg}$, have been reported for wood devolatilization [45]. In our model, a value of $418 \mathrm{~kJ} / \mathrm{kg}$ is used based on reference [10], in which a similar experimental setup was used to study wood devolatilization and combustion.

Table 5. Kinetic parameters used in the devolatilization model

\begin{tabular}{llll}
\hline Parameters & Pre-exponential factor $\left(\mathrm{s}^{-1}\right)$ & Activation energy $(\mathrm{kJ} / \mathrm{kg})$ & Reference \\
\hline$k_{w}$ & $5.13 \times 10^{10}$ & 88 & {$[33]$} \\
$k_{v}$ & $1.11 \times 10^{11}$ & 177 & {$[43]$} \\
$k_{t}$ & $9.29 \times 10^{9}$ & 149 & {$[43]$} \\
$k_{t v}$ & $4.28 \times 10^{6}$ & 107.5 & {$[43]$} \\
\hline
\end{tabular}




\section{Results and Discussion}

\subsection{Particle evolution}

In order to analyze the particle evolution during drying and devolatilization, the radial

221 distribution of particle temperature, moisture conversion, and volatiles conversion with specified particle conversion (defined as $\left.\left(X_{w} Y_{w 0}+X_{v o l} Y_{v o l 0}\right) /\left(Y_{w 0}+Y_{v o l 0}\right)\right)$ of $0.01,0.5$, and 0.9 are obtained under the conditions of $T_{g}=1214^{\circ} \mathrm{C}$ and $4 \mathrm{~mm}$ wood particle. As shown in Fig. 1 (a), when the total conversion is 0.01 , the temperature of the particle outer layer between a radius of $1.2 \mathrm{~mm}$ and $2.0 \mathrm{~mm}$ is in a range of $100-600^{\circ} \mathrm{C}$. A large amount of moisture is evaporated, while only a small amount of volatiles is released. When the particle conversion is 0.5 , the temperature of the entire particle is higher than $100^{\circ} \mathrm{C}$ as shown in Fig. $1(b)$, and the drying of moisture is almost finished. With a particle surface temperature of $\sim 850^{\circ} \mathrm{C}$ and a center temperature of $\sim 200^{\circ} \mathrm{C}$, significantly different conversion degrees are observed at different radius positions. When the particle conversion is 0.9 , the particle center temperature

231 is larger than $400^{\circ} \mathrm{C}$. All moisture is evaporated, and the volatiles only remain in the particle

232 center. From Fig. 1, it is also seen that the moisture front propagates inward to the center of the particle, followed by the volatiles released front. The results are consistent with other studies $[29,45,46]$. 
(a) Particle conversion: 0.01

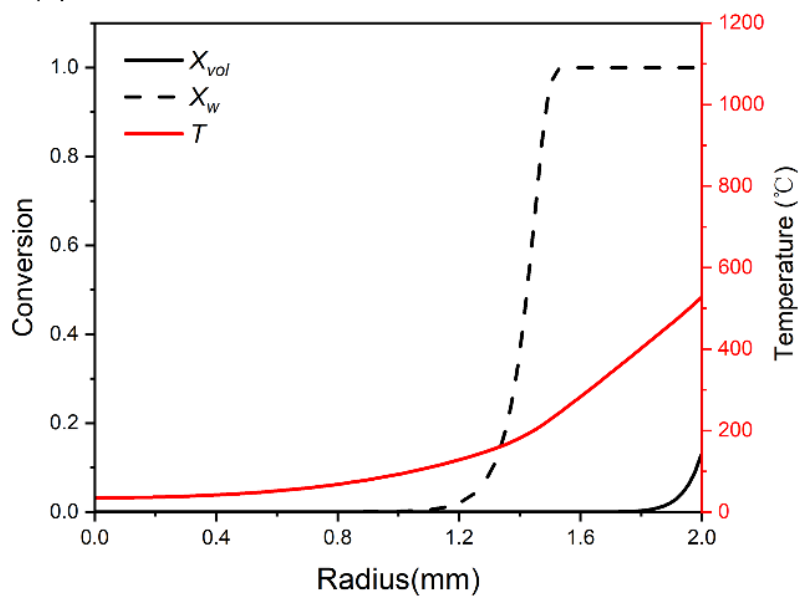

(b) Particle conversion: 0.5

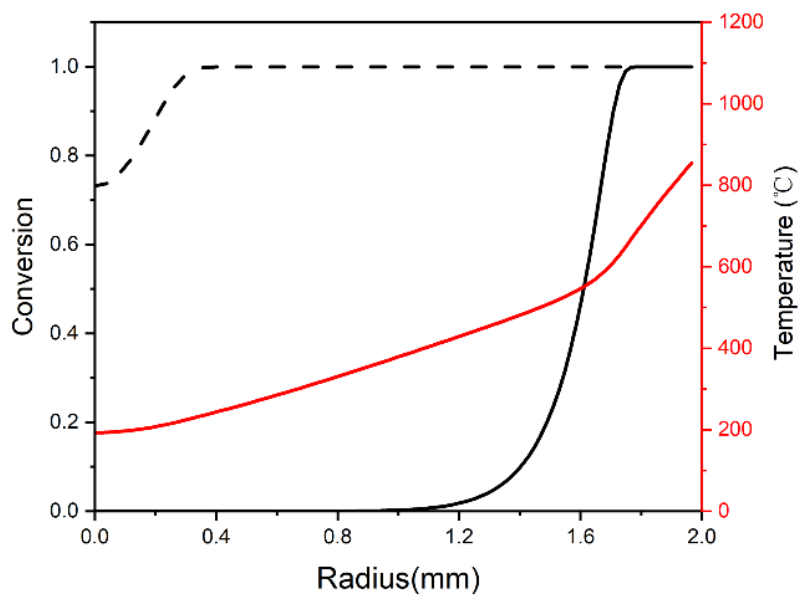

(c) Particle conversion: 0.9

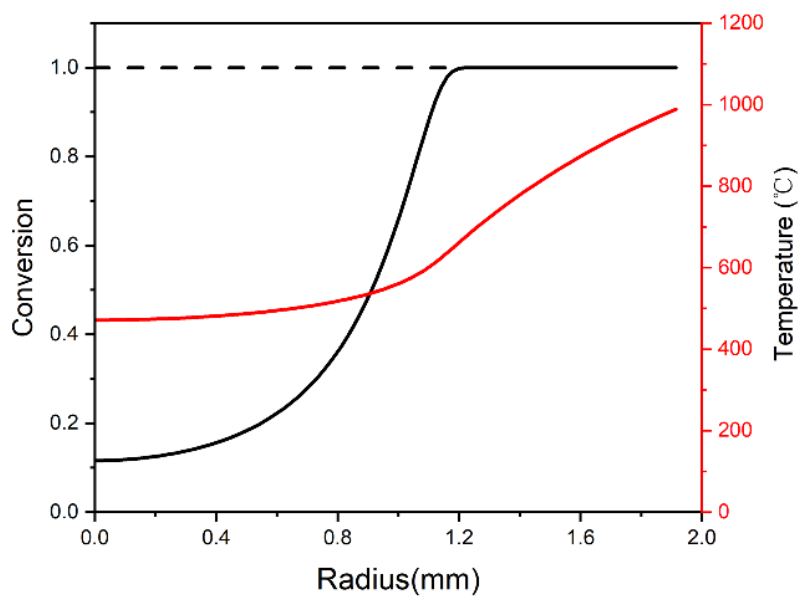

236 Figure. 1. Radial distribution of wood particle temperature $(T)$, conversion of moisture $\left(X_{w}\right)$ and 237 conversion of volatiles $\left(X_{v o l}\right)$ under different particle conversion $(0.01,0.5$, and 0.9 corresponding to ta 238 residence time of $0.27,3.37$, and $7.77 \mathrm{~s}$, Simulation conditions: $d_{p}=4 \mathrm{~mm}$, Moisture $=4.9 \mathrm{ar} \%$, Vol $=$ $\left.23983.7 \mathrm{db} \%, \mathrm{FC}=15.7 \mathrm{db} \%, T_{g}=1214^{\circ} \mathrm{C}, T_{w}=1014^{\circ} \mathrm{C}, 0.0 \% \mathrm{O}_{2}, \rho_{D B}=700 \mathrm{~kg} / \mathrm{m}^{3}\right)$. 


\subsection{Devolatilization time}

241 In Fig. $2(a) \sim(c)$, the experimental and predicted devolatilization times at different temperatures $\left(1214 / 1357 / 1400 / 1441^{\circ} \mathrm{C}\right)$ are compared for $\sim 4 \mathrm{~mm}$ beech, pine, and bamboo

243 wood. The devolatilization time decreases with increasing gas temperature due to an increased heat transfer, consistent with the results of other studies $[5,12,22,47-49]$. The predicted results agree with the experiments within about $\pm 25 \%$ for all three woody biomass.

In Fig. $2(d) \sim(f)$, the experimental and predicted devolatilization times of beech, pine, and bamboo wood with moisture content from 4.9 6.9\% (raw wood particle) to $\sim 50 \%$ at $1208^{\circ} \mathrm{C}$ are compared. An increased devolatilization time is observed with an increase of moisture content for all the wood types. A higher moisture content results in a larger heat consumption for the drying process and thereby delays devolatilization. Again, the predicted devolatilization time agrees with the experimental data within $\pm 25 \%$.

252 The effect of density on devolatilization time can also be observed in Fig. $2(a) \sim(f)$. The devolatilization time increases with an increase of the particle density. The reason is that the

254 devolatilization process is dominated by heat transfer for thermally-thick particles $[3,26]$. A higher density of the particles results in a lower heating rate, mainly due to an increased thermal capacity of the particles, and thereby increases the devolatilization time. Moreover, both the experimental and the model predicted results show that the devolatilization time increases

258 linearly with an increase in the density, consistent with the study of Haseli et al. [18]. The results 259 suggest that under the studied conditions, the density is the primary parameter that influences the devolatilization time of the biomass particles. 

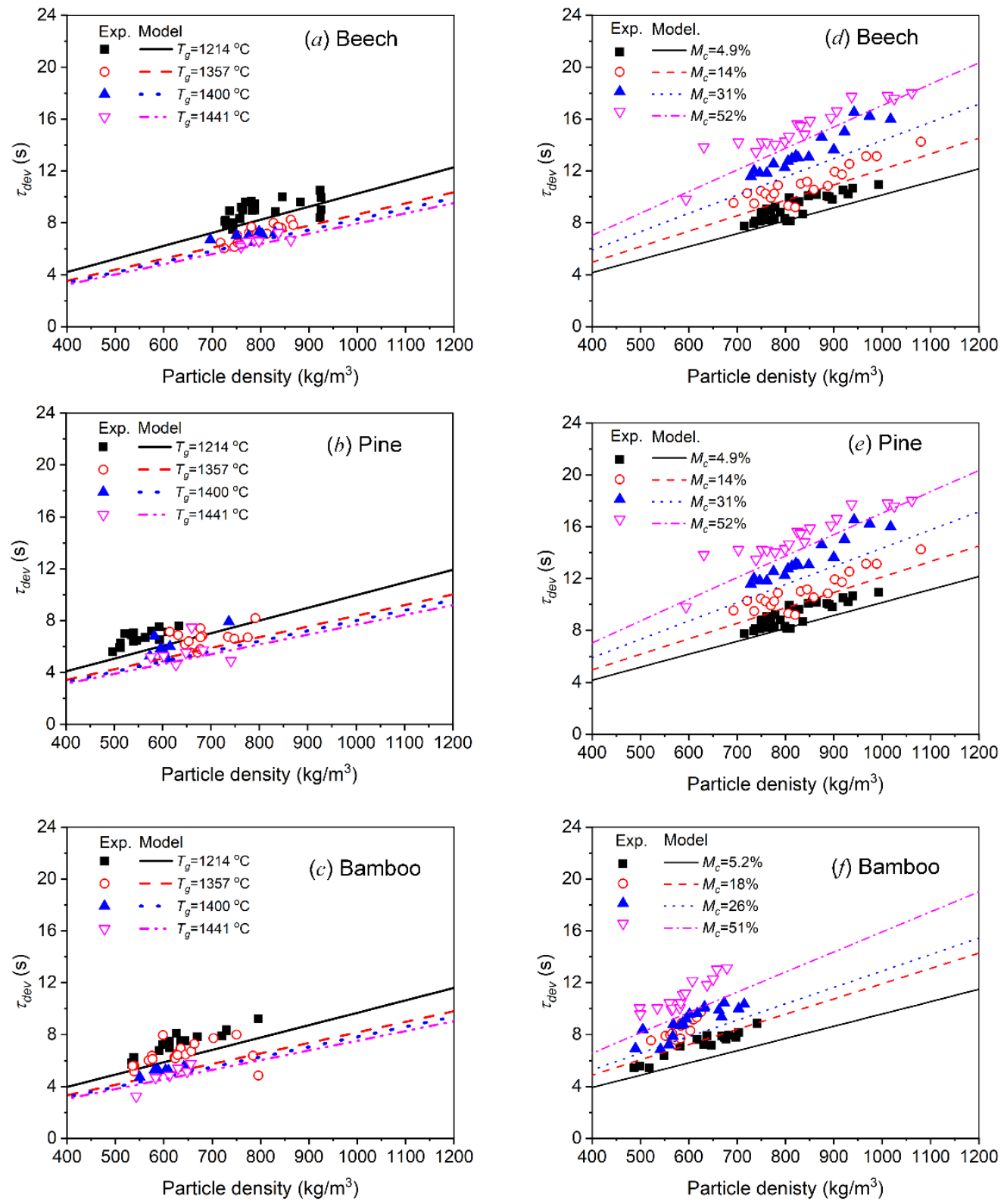

Figure. 2. A comparison between the experimental and model predicted devolatilization time with variation of gas temperature, moisture content and particle density for three different woods (beech, pine,

264 bamboo) in series I experiments (spherical particle), Fig. $2(a) \sim(c)$ show received particles devolatilized at different temperatures $\left(1214 / 1357 / 1400 / 14411^{\circ} \mathrm{C}\right)$, Figure. $2(d) \sim(f)$ show particles with different moisture content (as received particle basis, $\sim 15 \mathrm{wt} \%, \sim 30 \mathrm{wt} \%, \sim 50 \% \mathrm{wt} \%$ ) devolatilized at $1208^{\circ} \mathrm{C}$. Figure. 3 presents the experimental and predicted devolatilization time of $\sim 3 \mathrm{~mm}$ spherical wood particles (pine and beech) devolatilized with and without the presence of oxygen. With the presence of oxygen, the released volatiles are combusted near the particle, supplying extra heat and thereby leading to a small decrease in devolatilization time. However, the experimental 
results in Fig. 3 show that the presence of $4.4 \% \mathrm{O}_{2}$ only decreases the devolatilization time

272 slightly, compared to the case with $0.0 \% \mathrm{O}_{2}$. The particle density is still a key parameter 273 affecting the devolatilization time almost in a linear trend as shown in Fig. 3.

274

275 Figure. 3. A comparison between the experimental and model predicted devolatilization time with a 276 variation of wood types (Pine, Beech) and oxygen concentration $\left(0.0 \% \mathrm{O}_{2}, 4.4 \% \mathrm{O}_{2}\right)$ in series I 277 experiments (spherical particles), the particle diameter of pine and beech is $3.12 \mathrm{~mm}$ and $3.03 \mathrm{~mm}$, 278 respectively.

279 Figure. 4 shows the experimental and predicted devolatilization time of different woods with 280 or without torrefaction in series II experiments ( $\sim 3 \mathrm{~mm}$ cubic particles). The diameter used in 281 modeling is based on the equivalent particle volume. The volume equivalent method is simple 282 approximation which is proposed in previous studies [4,28]. The predicted devolatilization time 283 for different wood types, torrefaction treatment, particle moisture content, and particle size 284 conditions is in good agreement with measurements. The tendency in Fig. 4 further implies the 285 significant influence of particle density on devolatilization time. 


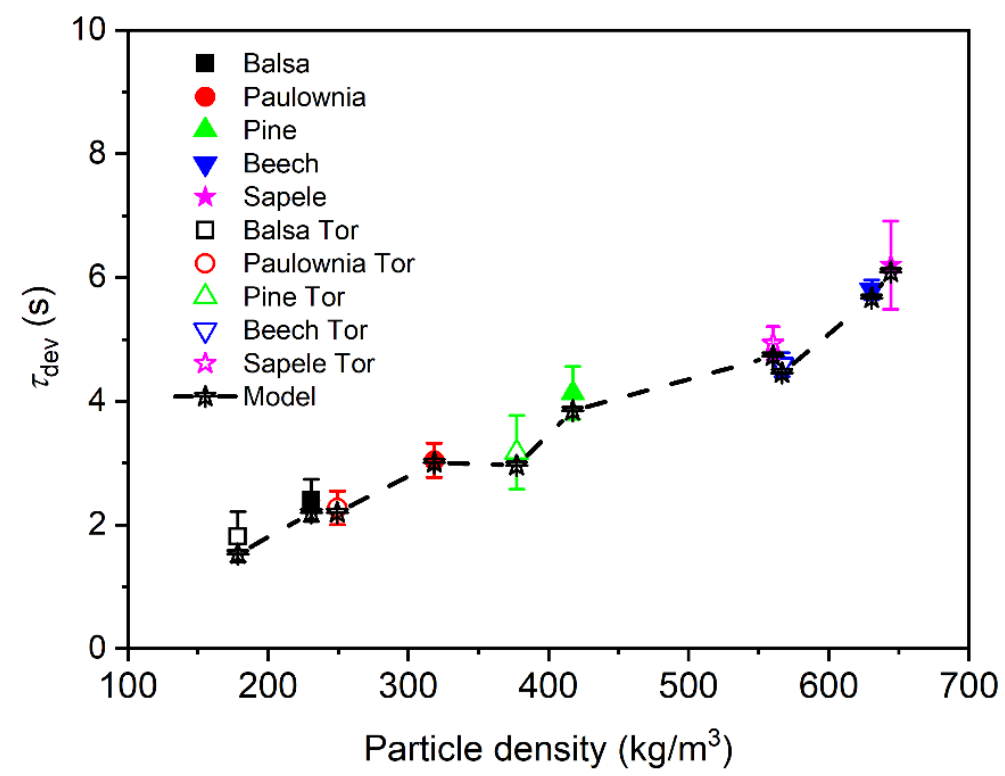

286

Figure. 4. A comparison between predicted and experimental devolatilization time of different wood with or without torrefaction in series II experiments (cubic particles), the oxygen concentration of bulk gas is about $2.8 \%$ and the temperature is $1256^{\circ} \mathrm{C}$.

\subsection{Sensitivity analysis}

\subsubsection{Physical properties}

There are several parameters in the model that may affect the predicted devolatilization time, such as emissivity $(\varepsilon)$, gas conductivity $\left(\lambda_{g}\right)$, char conductivity $\left(\lambda_{c}\right)$, raw wood conductivity $\left(\lambda_{B}\right)$, heat of devolatilization $\left(Q_{\text {pyro }}\right)$, convective heat transfer coefficient $\left(h_{c}\right)$, char pore size $\left(d_{\text {pore }}\right)$, raw wood pore size $\left(d_{p o r e B}\right)$, raw wood thermal capacity $\left(C_{p B}\right)$, char thermal capacity $\left(C_{p C}\right)$, wood true density $\left(\rho_{\text {true }}\right)$, shrinkage coefficient $(\varphi)$, and fixed carbon content (FC). Figure. 5 shows the results of a sensitivity analysis done by decreasing and increasing each parameter by $50 \%$ for a $4 \mathrm{~mm}$ wood particle devolatilized in $26.8 \% \mathrm{H}_{2} \mathrm{O} / 73.2 \% \mathrm{~N}_{2}$ at $T_{g}=1214^{\circ} \mathrm{C}$. The internal heat transfer related parameters $\left(\lambda_{C}, \lambda_{B}, C_{p B}\right)$ and the heat of devolatilization show significant influences $(>10 \%)$ on the devolatilization time, the external heat transfer related parameters $\left(\varepsilon, h_{c}\right)$ show a limited effects $(5 \% \sim 10 \%)$ on the predicted devolatilization time. 
controlled by external heat transfer for $4 \mathrm{~mm}$ particles $[3,26]$. Therefore, the assumption of using a constant emissivity in the modelling is reasonable in this work. The devolatilization time turned out to be insensitive to char pore size, gas conductivity, and raw wood pore size, due to its small contribution $(<20 \%)$ to particle effective conductivity during the devolatilization process. The shrinkage coefficient also shows an insignificant impact on devolatilization time for the $4 \mathrm{~mm}$ wood particle, which is consistent with a previous study[37]. The fixed carbon content is found to have no significant influence on devolatilization time, and the results are consistent with the study of $\mathrm{Bu}$ et al. $[13,15]$ as well as the experimental data shown in Fig. 3.

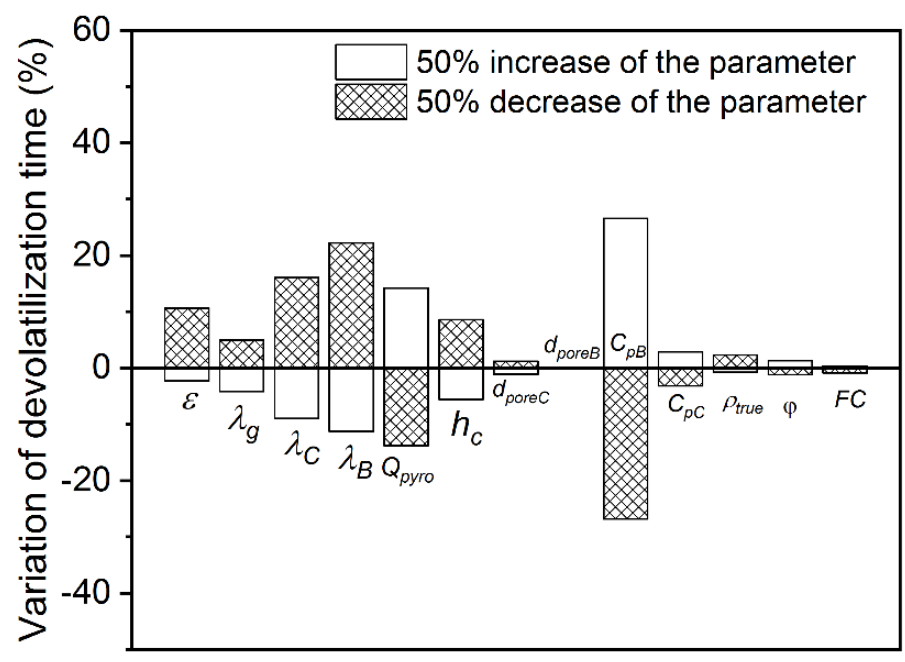

Figure. 5. Sensitivity analysis of the model with respect its physical properties $\left(T_{g}=1214^{\circ} \mathrm{C}, T_{w}=1014^{\circ} \mathrm{C}\right.$, Moisture $=4.9 \mathrm{ar} \%$, Ash $=0.6 \mathrm{ar} \%, d_{p}=4 \mathrm{~mm}, \rho_{D B}=700 \mathrm{~kg} / \mathrm{m}^{3}$ ). For the emissivity of the particle, the maximum value with reasonable physical meaning is 1 . Therefore, it is not $50 \%$ increase of the parameter.

\subsubsection{Devolatilization kinetics}

The influence of devolatilization kinetics is shown in Fig. 6, with Fig. 6 (a) showing the kinetic data and Fig. 6 (b) comparing the conversion history predicted by different kinetics. The kinetics of Wagenaar et al. [43] is derived by fast pyrolysis of pine wood sawdust in a drop tube reactor at temperatures $\left(300 \sim 600^{\circ} \mathrm{C}\right)$ and commonly used in single particle modelling 
$321[4,10,26,44]$. The devolatilization kinetics of Johansen et al. [50] (HT) is derived from small 322 wood particles $(<0.1 \mathrm{~mm})$ devolatilization in an entrained flow reactor at high temperatures $323\left(1200 \sim 1600^{\circ} \mathrm{C}\right)$. To cover a wide range of temperatures, Johansen et al. [4] proposed a 324 combination of the low temperature kinetics $\left(T<527^{\circ} \mathrm{C}\right.$, Wagenaar et al. [43]) and the high 325 temperature kinetics ( $T \geq 527^{\circ} \mathrm{C}$, Johansen et al. (HT) [4]). The devolatilization kinetics of 326 Roberts and Clough [51] was derived from a single beech wood particles devolatilization with 327 a heating rate $20^{\circ} \mathrm{C} / \mathrm{min}$ at low temperatures $\left(275^{\circ} \mathrm{C} \sim 435^{\circ} \mathrm{C}\right)$. The devolatilization kinetics of 328 Johansen et al. [50] (TGA) was derived by TGA using a heating rate $2^{\circ} \mathrm{C} / \mathrm{min}$. According to Fig. $3296(b)$, the kinetics of Johansen et al. (HT) [4] underestimate the devolatilization time, because 330 it is too fast at low temperatures (it is $10^{6}$ times faster than that of Wagenaar et al. [43] when 331 temperature is $<400^{\circ} \mathrm{C}$ ). The devolatilization kinetics of Wagenaar et al. [43] and Johansen et 332 al. (Two) [4] lead to a similar particle conversion history. This implies that the volatiles are 333 almost fully released at low temperatures $\left(<600^{\circ} \mathrm{C}\right)$ during devolatilization of the $4 \mathrm{~mm}$ particle. 334 Therefore, it is more reasonable to use the kinetics derived at low temperatures $\left(<600^{\circ} \mathrm{C}\right)$ in the 335 single particle model for large particles. Although the devolatilization kinetics of low 336 temperature (Wagenaar et al. [43], Roberts and Clough [52], and Johansen et al. [50] (TGA)) are 337 significantly different (a magnitude of -2 to 7 , Wagenaar et al. [43] as basis), the devolatilization 338 times predicted by different devolatilization kinetics (Wagenaar et al. [43]: $9.50 \mathrm{~s}$, Roberts and 339 Clough [52]: $11.71 \mathrm{~s}$, Johansen et al. [50] (TGA): 12.45s) have a maximum difference of 31\%. 340 Therefore, for the devolatilization of large particles at high temperatures, low-temperature 341 devolatilization kinetics should be chosen in the modelling, and the modelling results are not 342 sensitivity to the sleeted low-temperature devolatilization kinetics. 

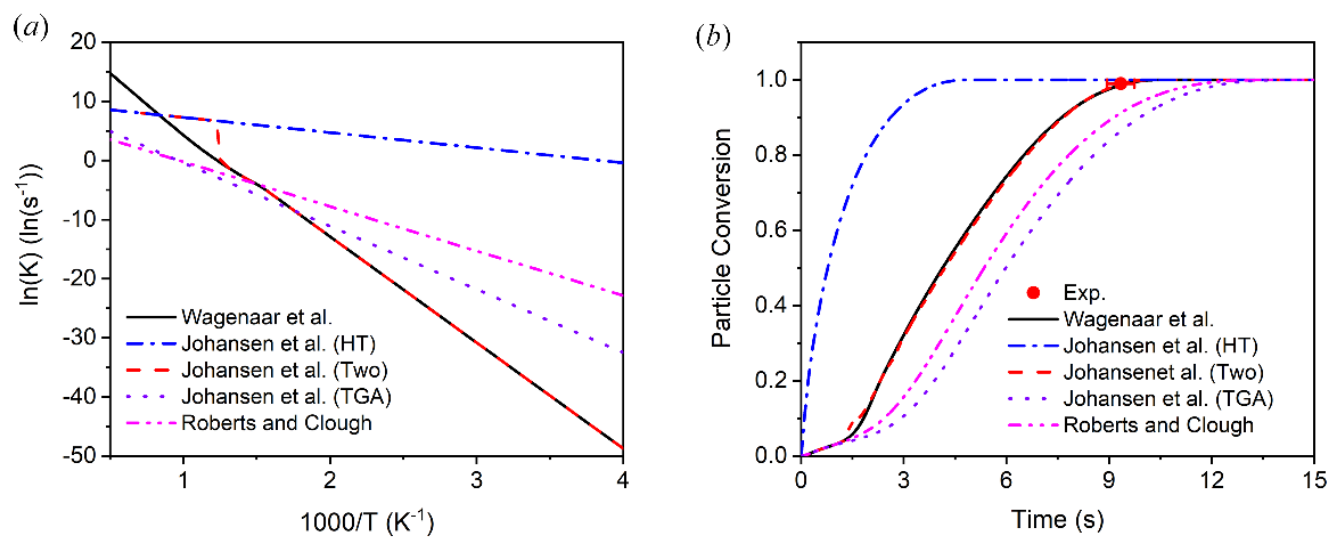

Figure. 6. (a): five devolatilization kinetics (Wagenaar et al. [43], Johansen et al.[50] high temperature

345 kinetic: Johansen et al. (HT), Johasnen et al.[4] two regime kinetics $\left(T \geq 527{ }^{\circ} \mathrm{C}\right.$, Johansen et al. (HT),

$346 T<527^{\circ} \mathrm{C}$, Wagenaar et al.): Johasnen et al. (Two), Johansen et al. [50] TGA kinetic: Johansen et al. (TGA),

347 and Roberts and Clough's kinetic [52]); (b): The effects of five devolatilization kinetics on modelling

348 results. (Beech wood, $T_{g}=1214^{\circ} \mathrm{C}, T_{w}=1014^{\circ} \mathrm{C}$, Moisture $=4.9 \mathrm{ar} \%, \mathrm{Vol}=83.7 \mathrm{db} \%, \mathrm{FC}=15.7 \mathrm{db} \%$,

349 Ash $\left.=0.6 \mathrm{db} \%, d_{p}=4 \mathrm{~mm}, \rho_{D B}=800 \mathrm{~kg} / \mathrm{m}^{3}\right)$.

350 Figure.7 shows the results of scaling the devolatilization rate with 0.1 and 10 times of the

351 Wagenaar et al. [43] for different size wood particles devolatilized at $1214^{\circ} \mathrm{C}$. Again, the 352 devolatilization rate has limited impact on the devolatilization time of large particles $\left(d_{p}=1\right.$ $353 \mathrm{~mm}(< \pm 25 \%)$ and $\left.d_{p}=10 \mathrm{~mm}(< \pm 15 \%)\right)$. The influence of devolatilization rate on 354 devolatilization time becomes larger for a small particle (up to $\pm 60 \%$ ). It indicates that the 355 regime of biomass devolatilization transits from the heat transfer dominated regime to a 356 kinetically controlled regime with decreasing particle size from $10 \mathrm{~mm}$ to $0.1 \mathrm{~m}$. 


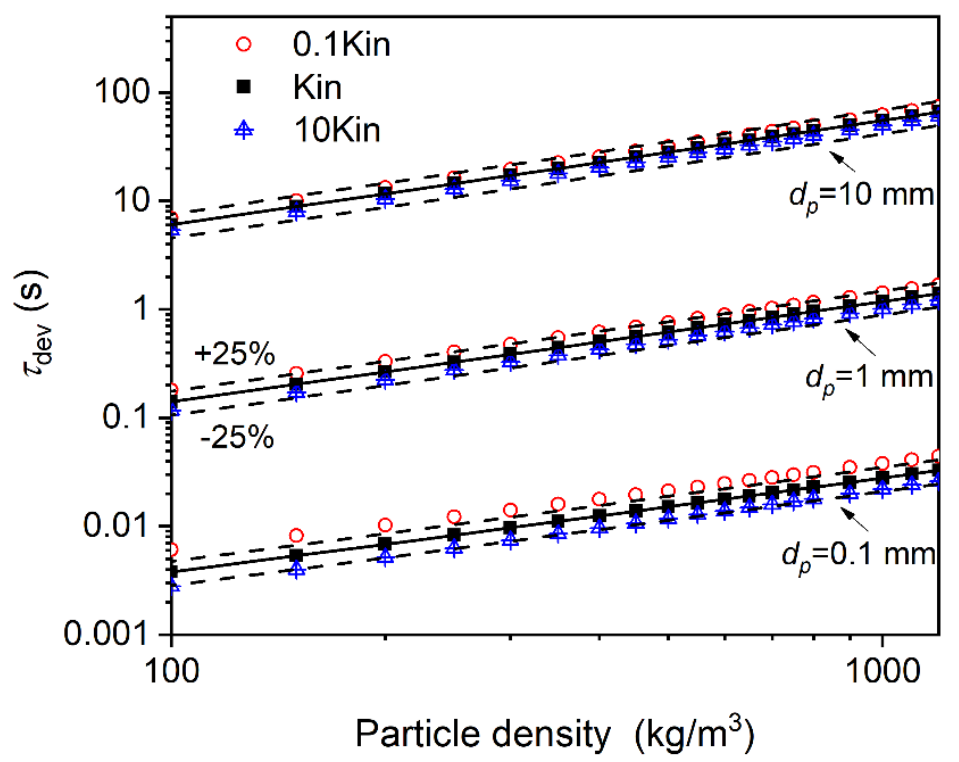

Figure. 7. Sensitivity analysis of the influence of devolatilization rate and particle size on devolatilization time. The dash (---) line are the $\pm 25 \%$ deviation line based on the results of using Wagenaar et al. kinetics $\left(T_{g}=1214^{\circ} \mathrm{C}, T_{w}=1014^{\circ} \mathrm{C}\right.$, Moisture $=4.9 \mathrm{ar} \%, \mathrm{Vol}=83.7 \mathrm{db} \%, \mathrm{FC}=15.7 \mathrm{db} \%$, Ash $\left.=0.6 \mathrm{db} \%\right)$.

\section{Simple correlation for devolatilization time}

According to the results and discussion in Section 4, the devolatilization time is sensitive to gas/wall temperature, moisture content, particle density, and particle size, and insensitive to volatiles content. The devolatilization time is found to increase linearly with the increase of particle density. A range of material properties (such particle density, size) can influence the devolatilization time, However, the different wood species seem to be relatively similar with respect to their material properties. If the change in wood density is accounted for, the devolatilization time can be calculated reasonably. Therefore, it is possible to derive a theoretical based simple correlation to estimate the devolatilization time based on our detailed devolatilization model. In this way, the devolatilization time can be estimated by readily measurable properties (such as particle density, size, and operation conditions).

\subsection{Parametric analysis}

To derive a correlation to predict devolatilization time, a parametric analysis of gas velocity, 


\subsubsection{Effects of gas velocity}

According to Fig. 5, it seems that by changing the convection heat transfer coefficient by $\pm 50 \%$, the predicted devolatilization time is changed only by about $10 \%$. A change in the gas velocity influences the external convective heat transfer coefficient and thereby the devolatilization time. Figure. 8 shows an analysis of the influence of gas velocity. The devolatilization time is insensitive to gas velocity for $10 \mathrm{~mm}$ particles, because the contribution of convection is small compared to radiative heat transfer. The gas velocity seems to have a maximum of $18 \%$ effect on the predicted devolatilization time for small wood particles with $d_{p}=1 \mathrm{~mm}$ and $0.1 \mathrm{~mm}$. However, such a difference is acceptable due to the shorter devolatilization time $(<2 \mathrm{~s})$ for particle sizes smaller than $1 \mathrm{~mm}$.

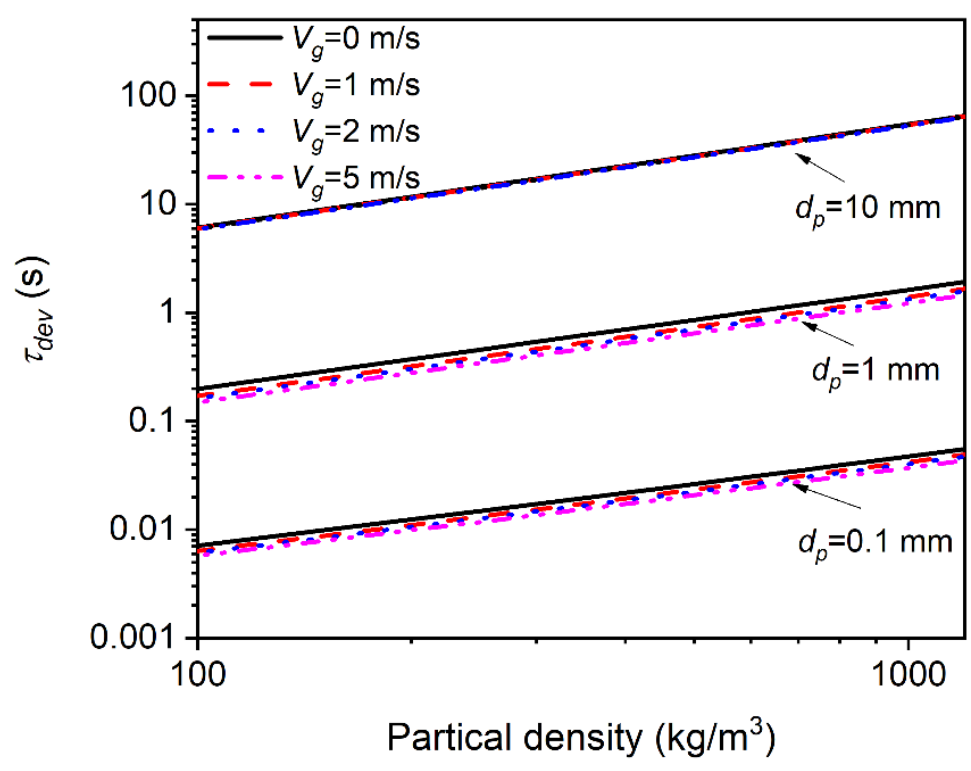

Figure. 8. Parametric analysis influence of gas velocity on modelling results of different particle size. $\left(T_{g}\right.$ $=T_{w}=1200^{\circ} \mathrm{C}$, Moisture $\left.=0.0 \%, \mathrm{Vol}=88.0 \%, \mathrm{FC}=12.0 \%, \mathrm{Ash}=0.0 \%\right)$

\subsubsection{Effects of gas temperature}

Figure. 9 shows the influence of gas temperature on predicted devolatilization time for different particle size $\left(d_{p}=0.1 \mathrm{~mm}, 1 \mathrm{~mm}, 10 \mathrm{~mm}\right)$ with variations of particle density. The predicted 
391 devolatilization times decrease with an increase of gas temperature, consistent with other 392 studies $[4,21,22,24]$. Moreover, the predicted devolatilization time increases linearly with the 393 increase of particle density for all selected temperatures.

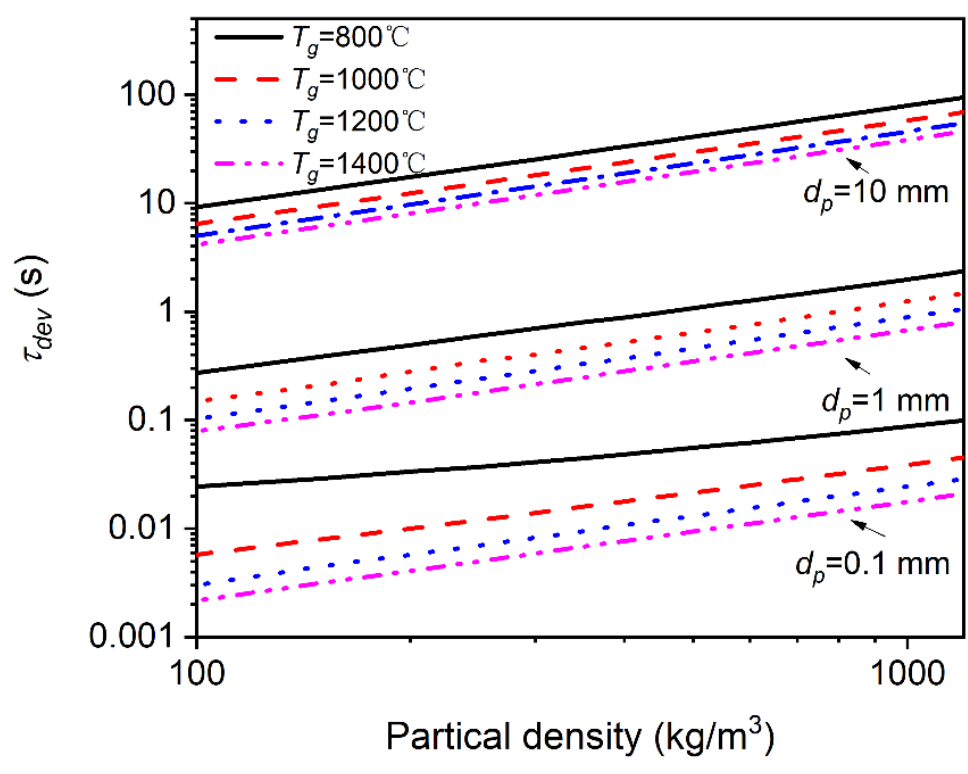

394

395 Figure. 9. Parametric analysis influence of gas temperature on modelling results of different particle size.

$396 \quad\left(V_{g}=3 \mathrm{~m} / \mathrm{s}\right.$, Moisture $\left.=0.0 \%, \mathrm{Vol}=88.0 \%, \mathrm{FC}=12.0 \%, \mathrm{Ash}=0.0 \%\right)$

\subsubsection{Effects of moisture content}

Figure. 10 show the results of model calculations for different particle size $\left(d_{p}=0.1 \mathrm{~mm}, 1 \mathrm{~mm}\right.$,

$40010 \mathrm{~mm})$ and moisture content $(0.0 \%, 20.0 \%, 50.0 \%)$ devolatilized at $T_{g}=1200^{\circ} \mathrm{C}$. With the 401 increase of moisture content from $0.0 \%$ to $50.0 \%$, the devolatilization time is delayed $45 \%$, $40254 \%$, and $68 \%$ for $d_{p}=0.1 \mathrm{~mm}, d_{p}=1 \mathrm{~mm}$, and $d_{p}=10 \mathrm{~mm}$, respectively. The predicted 403 devolatilized times increase with moisture content as also reported in previous studies $[7,10,14]$. 


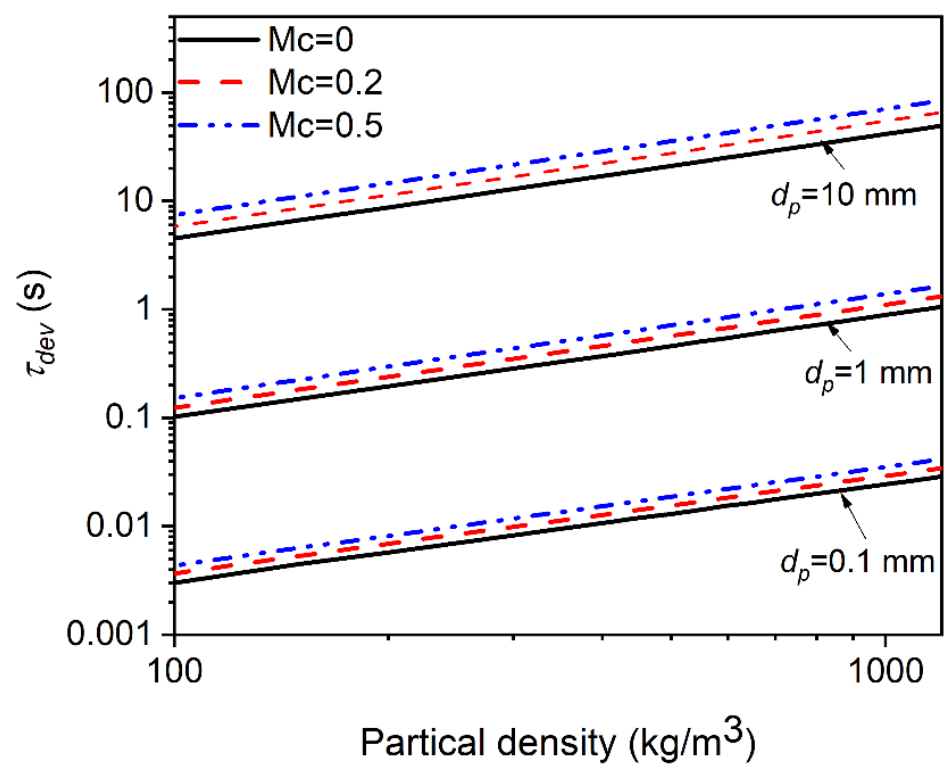

Figure. 10. Parameter analysis influence of moisture content on modelling results of different particle size. $\left(V_{g}=3 \mathrm{~m} / \mathrm{s}, T_{g}=1200^{\circ} \mathrm{C}, \mathrm{Vol}=88.0 \%, \mathrm{FC}=12.0 \%\right.$, Ash $\left.=0.0 \%\right)$

\subsection{Simple devolatilization time model}

According to the sensitivity analysis in Section 4.3 and the parametric analysis in Section 5.1, we can conclude that the devolatilization time is most sensitive to particle size, gas temperature, moisture content, and particle density. According to the sensitivity analysis shown in Fig.5, it is seen that changing the fixed carbon content of $20 \%$ by $\pm 10 \%$ does not have a significant influence on devolatilization time. The reason is that the devolatilization of millimeter-sized biomass particle is controlled by internal and external heat transfer and the heat of devolatilization, which is not significantly affected by volatile content. The devolatilization time is relatively insensitive to gas velocity as shown in Fig. 8, and the devolatilization kinetics have a limited influence on the predicted devolatilization time for large particles. According to the experimental results in Section 4.2 and the parametric analysis in Section 5.1, the devolatilization time increases linearly with the particle density when the gas temperature, moisture content, and particle size are constant. Therefore, it is possible to derive a simple correlation to predict devolatilization time,

$$
\tau_{d e v}=f\left(d_{p}, M_{c}, T_{g}\right) \rho_{D B}
$$


Here, $f\left(d_{p}, M_{c}, T_{g}\right)$ is a slope to correlate particle density and devolatilization time. It can be correlated as a ternary function of particle size, moisture content, and gas temperature. To correlate the function of $f\left(d_{p}, M_{c}, T_{g}\right)$, a series of data with changing particle density, particle size, gas temperature, and moisture content are generated by using the detailed devolatilization model in Section 3. Then $f\left(d_{p}, M_{c}, T_{g}\right)$ is fitted from the data based on Eq. (7). The variation of particle density, particle size, gas temperature, and moisture content used to generate database are listed as below:

(1) Particle density: $50 \sim 800 \mathrm{~kg} / \mathrm{m}^{3}$ with an increment step of $50 \mathrm{~kg} / \mathrm{m}^{3}, 900 \sim 1200 \mathrm{~kg} / \mathrm{m}^{3}$ with an increment step of $100 \mathrm{~kg} / \mathrm{m}^{3}$, the number of points is 20 .

(2) Particle size: $0.1 \sim 1 \mathrm{~mm}$ with an increment of $0.1 \mathrm{~mm}, 1.5 \sim 10 \mathrm{~mm}$ with an increment step of $0.5 \mathrm{~mm}$, the number of points is 37 .

(3) Gas temperature: $800,1000,1100,1200,1300,1400,1500$, and $1600^{\circ} \mathrm{C}$

(4) Moisture content: 6 moisture contents as received based $0 \%, 10 \%, 20 \%, 30 \%, 40 \%, 50 \%$.

The matrix size of the generated database is $20 \times 37 \times 8 \times 6$.

\subsection{Discussion of $f\left(d_{p}, M_{c}, T_{g}\right)$}

Figure. 11 (a) presents the effect of gas temperature on the value of $f\left(d_{p}, M_{c}, T_{g}\right)$. The $f\left(d_{p}, M_{c}\right.$, $T_{g}$ ) monotonically and nonlinearly decreases with temperature. A monotonically nonlinear function with the formulation of $\left(a+b /\left(T_{g}^{c}\right)\right)$ is selected to represent the influence of gas temperature. Figure.11 (b) shows that the value of $f\left(d_{p}, M_{c}, T_{g}\right)$ monotonically and nonlinearly increases with moisture content. Thus, a polynomial function with the formulation of $\left(d M_{c}+e M_{c}^{2}\right)$ is selected to represent the influence of particle moisture content. According to Fig. $11(a)$ and Fig. $11(b), f\left(d_{p}, M_{c}, T_{g}\right)$ monotonically and nonlinearly increases with particle size. A typical power-law expression: $f d_{p}{ }^{n}$, as reported in references [21,22,24], is selected to represent the influence of particle size. The value of the coefficient $n$ is in a range of $1 \sim 2$ as discussed by Diego et al. [24]. Finally, the Eq. (8) is suggested to be used for the calculation of devolatilization time.

$$
\tau_{\mathrm{dev}}=f\left(d_{p}, M_{c}, T_{g}\right) \rho_{D B}=\left(a+\frac{b}{T_{g}^{c}}+d M_{c}-e M_{c}^{2}\right) f d_{p}^{n} \rho_{D B}
$$


Here $a, b, c, d, e, f$, and $n$ are coefficients which can be regressed ("Isqcurvefit" function in MATLAB 2018 $\mathrm{a}^{\circledR}$ used) from the devolatilization time calculated by using the devolatilization 451 model. With some arrangement, the simple correlation to predict the devolatilization time can be expressed as Eq. (9).

$$
\tau_{\text {dev }}=0.0209\left(1000 d_{p}\right)^{1.8600}\left(0.0072+\frac{0.0591}{\left(T_{g} / 1000\right)^{2.5313}}+0.0440 M_{c}-0.0117 M_{c}^{2}\right) \rho_{D B}
$$
To evaluate the simple correlation, the devolatilization time calculated by Eq. (9) were

Here, $d_{p}$ is particle size, $\mathrm{m}, T_{g}$ is gas temperature, $\mathrm{K}, M_{c}$ is particle moisture content (dry based), and $\rho_{D B}$ is particle density, $\mathrm{kg} / \mathrm{m}^{3}$.

The value of $n$ is 1.86 in good agreement with the range found in other studies [21,22,24]. Since the correlation is used to describe a spherical wood particle, $d_{p}$ should be the equivalent particle diameter (diameter of a sphere having the same volume as the particle) multiplied by the shape factor (surface area of a sphere having the same volume as the initial particle/initial surface area of the particle) for non-spherical particle as suggested by Diego et al. [24]. In some cases, when the gas temperature is different from the wall temperature, a modification of using the average temperature of the gas and the wall is recommended. (a) Gas Temperature

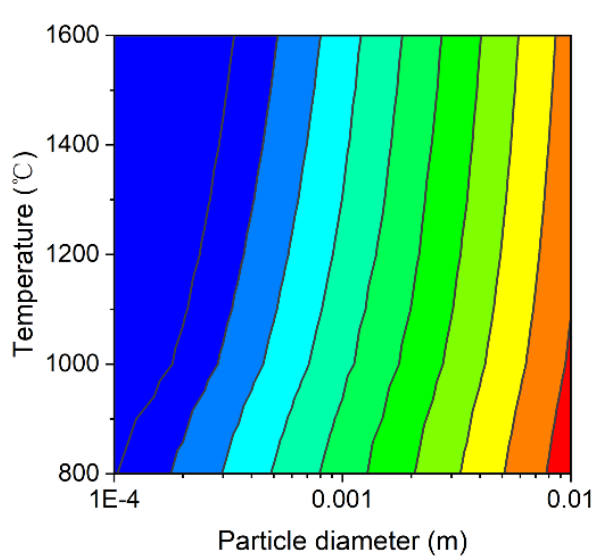

(b) Moisture Content

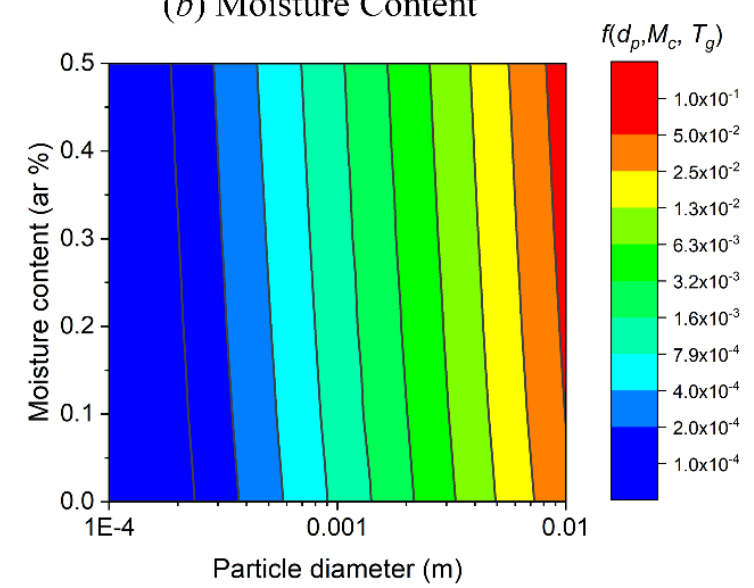

Figure. 11. (a) the influence of gas temperature on the value of $f\left(d_{p}, M_{c}, T_{g}\right),(b)$, the influence of moisture content on the value of $f\left(d_{p}, M_{c}, T_{g}\right)$

\subsection{Model validation} compared with experimental data from other studies as shown in Fig. 12. The experimental data 
include both single particle experiments with temperature higher than $1000^{\circ} \mathrm{C}[5,8,9,19,20]$ and lower than $1000^{\circ} \mathrm{C}[10,20]$. Even though the experimental data from $\mathrm{Lu}$ et al. [8,9] were obtained from varying conditions (e.g., wood with and without torrefaction, torrefaction temperature and time, $\mathrm{KCl}$ content, etc.), the correlation gives a reasonable estimation of the devolatilization time. Although the generated database used to obtain Eq. (9) is for hightemperature $\left(>1000^{\circ} \mathrm{C}\right)$, it still gives a reasonable estimation of devolatilization time in single particle combustor for the low-temperature cases as shown in Fig. $12(b)$. Generally, the predicted results agree with the experiments within about $\pm 25 \%$. While other empirical correlations $[7,21,22,24]$ were obtain and validated by the specified experimental conditions, this simple correlation based on the 1D model validated by experimental data obtained from different experimental setup with different operating conditions, it appears to applicable at a wide range of conditions with known operating temperature $\left(1000^{\circ} \mathrm{C} \sim 1600^{\circ} \mathrm{C}\right)$, particle size $(0.1 \mathrm{~mm}-10 \mathrm{~mm})$, particle density and moisture content $(0 \% \sim 50 \%)$. It should be noted that the simple correlation is only validated with the experimental particle size $(1 \mathrm{~mm} \sim 10 \mathrm{~mm}$.) in this work. The uncertainty of the simple model may increase for small particle size (e.g. $0.1 \mathrm{~mm}$ ) which the effects of kinetics on devolatilization becomes significant.

(a)

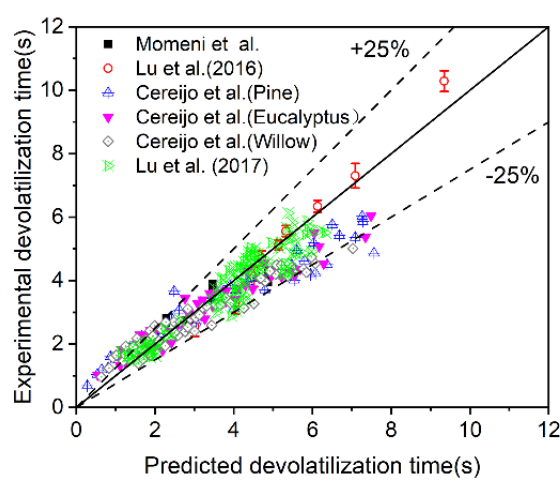

(b)

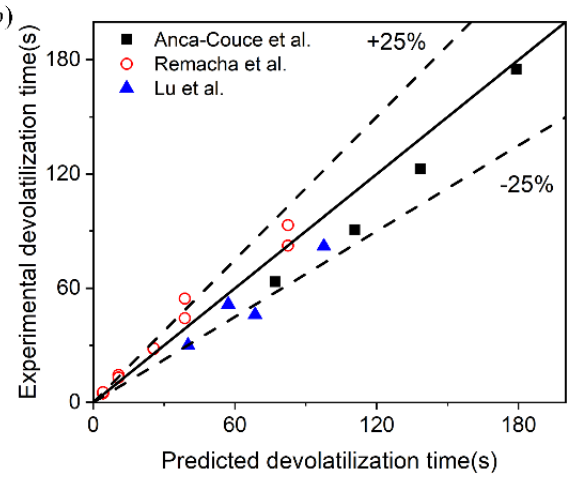

Figure. 12. Comparison of single particle experimental and predicted devolatilization time from various references: Fig. $13(a)$ : Momeni et al. [5] ( $d_{p}: 1.65 \sim 3.0 \mathrm{~mm}, T_{g}=1200^{\circ} \mathrm{C}, T_{w}=1000^{\circ} \mathrm{C}($ estimated)), $\mathrm{Lu}$ et al.(2016) [8] $\left(d_{p}: 3.00 \sim 5.00 \mathrm{~mm}, T_{g}=1231^{\circ} \mathrm{C}, \mathrm{T}_{\mathrm{w}}=1031^{\circ} \mathrm{C}\left(\right.\right.$ estimated)), Cereijo et al. [19] $\left(d_{p}: 1.0 \sim\right.$ $\left.5.0 \mathrm{~mm}, T_{g}=1550^{\circ} \mathrm{C}, T_{w}=900^{\circ} \mathrm{C}\right)$, Lu et al. (2017) [9] $\left(d_{p}: 3.00 \sim 5.00 \mathrm{~mm}, T_{g}=1225^{\circ} \mathrm{C}, T_{w}=1025^{\circ} \mathrm{C}\right.$ (estimated)); Fig. 13 (b): Anca-Couce et al. [53] ( $\left.d_{p}: 9.9 \mathrm{~mm}, T_{g}=T_{w}=550 \sim 590^{\circ} \mathrm{C}\right)$; Remacha et al. [20] $\left(d_{p}: 3.0 \sim 15.0 \mathrm{~mm}, T_{g}=1200^{\circ} \mathrm{C}, T_{w}=1200^{\circ} \mathrm{C}\right)$, Lu et al. [10] $\left(d_{p}: 9.5 \mathrm{~mm}, T_{g}=777{ }^{\circ} \mathrm{C}, T_{w}=\right.$ $\left.1003^{\circ} \mathrm{C}\right)$ 


\section{Implications and conclusions}

494 Single particle devolatilization experiments with 8 different wood samples at temperatures from

4951200 to $1450{ }^{\circ} \mathrm{C}$ were conducted with both spherical and cubic particles, and the influence of 496 changes in moisture content, and particle density was also studied. A 1D wood particle 497 devolatilization model based on the work of Johansen et al. [4] was modified. The model 498 accounts for internal and external heat transfer, water evaporation and devolatilization kinetics. 499 The detailed 1D devolatilization model was validated by using the experimental data, and both 500 experiments and modelling show that the devolatilization time increases linearly with the 501 increase of particle density.

502 A sensitivity analysis showed that the devolatilization time predicted by the $1 \mathrm{D}$ model is 503 influenced significantly by material thermal properties, such as particle heat capacity, particle 504 conductivity and enthalpy of pyrolysis reactions. The devolatilization kinetics have limited 505 effects on the simulated devolatilization time for large wood particles (>1mm), suggesting that 506 the devolatilization process is mainly heat transfer controlled. The particle density, size, gas 507 temperature, and moisture content have significant effects on the devolatilization time, while 508 parameters, such as mass fraction of volatiles, gas velocity, only have small influences. 509 Therefore, the devolatilization time be reasonably well predicted using one set kinetics by 510 changing the moisture content, particle density, particle size, and gas temperature for different 511 woody biomass particle.

512 Based on the finding that the devolatilization time increases linearly with the increase of particle 513 density, a simple devolatilization correlation was derived from the 1D model and validated by 514 experimental data from other references. The results show that the correlation can be used to 515 predict the devolatilization time with an accuracy of $\pm 25 \%$ for millimeter-sized woody biomass 516 particle under different operating conditions.

\section{Acknowledgment}

518 This study is supported by Sino-Danish collaboration project (DANCNGAS) funded by 519 Innovation Fund Denmark, and Minerals and Cement Process Technology (MiCeTech) funded 
520 by the Danish National Advanced Technology Foundation, FLSmidth A/S, Hempel A/S, and 521 DTU Chemical Engineering. This study is also supported by National Natural Science 522 Foundation of China (51876068), Nature Science Foundation of Guangdong Province 523 (2018A030313800).

524 Nomenclature

\begin{tabular}{|c|c|c|}
\hline$C_{p}$ & Heat capacity of particle & $\mathrm{J} / \mathrm{kg} / \mathrm{K}$ \\
\hline$C_{p B}$ & Heat capacity of raw wood & $\mathrm{J} / \mathrm{kg} / \mathrm{K}$ \\
\hline$C_{p C}$ & Heat capacity of char & $\mathrm{J} / \mathrm{kg} / \mathrm{K}$ \\
\hline$d_{p}$ & Particle size & $\mathrm{m}$ \\
\hline$d_{\text {poreB }}$ & Raw wood pore size & $\mathrm{m}$ \\
\hline$d_{\text {poreC }}$ & Char pore size & $\mathrm{m}$ \\
\hline$F C$ & Fixed carbon & - \\
\hline$h_{c}$ & Convective heat transfer coefficient & $\mathrm{W} / \mathrm{m}^{2} / \mathrm{s}$ \\
\hline$m_{p}$ & Mass of particle & $\mathrm{kg}$ \\
\hline$M_{c}$ & Moisture content & - \\
\hline$Q_{\text {pyro }}$ & Heat of devolatilization & $\mathrm{J} / \mathrm{kg}$ \\
\hline$Q_{w}$ & Heat of evaporation & $\mathrm{J} / \mathrm{kg}$ \\
\hline$r$ & Radius & $\mathrm{m}$ \\
\hline$t$ & Time & s \\
\hline$T$ & Particle temperature & $\mathrm{K}$ \\
\hline Vol & Volatiles & - \\
\hline$X$ & Total conversion & - \\
\hline$X_{\text {vol }}$ & Conversion of volatiles & - \\
\hline$X_{w}$ & Conversion of Moisture & - \\
\hline$Y$ & Mass fraction & - \\
\hline
\end{tabular}

526 Greek symbols
$\lambda_{g}$
Conductivity of gas
$\mathrm{W} / \mathrm{m} / \mathrm{K}$ 


$\begin{array}{lll}\lambda c & \text { Conductivity of char } & \mathrm{W} / \mathrm{m} / \mathrm{K} \\ \lambda_{B} & \text { Conductivity of apparent biomass particle } & \mathrm{W} / \mathrm{m} / \mathrm{K} \\ \lambda_{p} & \text { Conductivity of particle } & \mathrm{W} / \mathrm{m} / \mathrm{K} \\ \varepsilon & \text { Volume fraction } & - \\ \rho_{\text {rue }} & \text { Wood true density } & \mathrm{kg} / \mathrm{m}^{3} \\ \rho_{D B} & \text { Particle density } & \mathrm{kg} / \mathrm{m}^{3} \\ \xi & \text { Emissivity } & - \\ \sigma & \text { Stenfan-Boltzmann constant } & \mathrm{J} /\left(\mathrm{m}^{2} \mathrm{~K}^{4} \mathrm{~s}\right) \\ \varphi & \text { Particle shrinkage } & - \\ \tau_{d e v} & \text { Devolatilization time } & \mathrm{s}\end{array}$

\section{References}

[1] Roni MS, Chowdhury S, Mamun S, Marufuzzaman M, Lein W, Johnson S. Biomass co-firing technology with policies, challenges, and opportunities: A global review. Renew Sustain Energy Rev 2017;78:1089-101.

[2] Haberle I, Skreiberg Ø, Lazar J, Haugen NEL. Numerical models for thermochemical degradation of thermally thick woody biomass, and their application in domestic wood heating appliances and grate furnaces. Prog Energy Combust Sci 2017;63:204-52.

[3] Gómez-Barea A, Leckner B. Modeling of biomass gasification in fluidized bed. Prog Energy Combust Sci 2010;36:444-509.

[4] Johansen JM, Jensen PA, Glarborg P, Mancini M, Weber R, Mitchell RE. Extension of apparent devolatilization kinetics from thermally thin to thermally thick particles in zero dimensions for woody biomass. Energy 2016;95:279-90.

[5] Momeni M, Yin C, Kær SK, Hansen TB, Jensen PA, Glarborg P. Experimental Study on Effects of Particle Shape and Operating Conditions on Combustion Characteristics of Single Biomass Particles. Energy Fuels 2013;27:507-14.

[6] Remacha MP, Jiménez S, Ballester J. Devolatilization of millimeter-sized biomass particles at high temperatures and heating rates. Part 1: Experimental methods and results. Fuel 2018;234:757-69.

[7] Mason PE, Darvell LI, Jones JM, Pourkashanian M, Williams A. Single particle flamecombustion studies on solid biomass fuels. Fuel 2015;151:21-30.

[8] Lu Z, Jian J, Jensen PA, Wu H, Glarborg P. Influence of Torrefaction on Single Particle Combustion of Wood. Energy Fuels 2016;30:5772-8.

[9] Lu Z, Jian J, Jensen PA, Wu H, Glarborg P. Impact of $\mathrm{KCl}$ impregnation on single particle combustion of wood and torrefied wood. Fuel 2017;206:684-9.

551 [10] Lu H, Robert W, Peirce G, Ripa B, Baxter LL. Comprehensive study of biomass particle 
combustion. Energy Fuels 2008;22:2826-39.

[11] Di Blasi C. Kinetic and Heat Transfer Control in the Slow and Flash Pyrolysis of Solids. Ind Eng Chem Res 1996;35:37-46.

[12] Pyle DL, Zaror CA. Heat transfer and kinetics in the low temperature pyrolysis of solids. Chem Eng Sci 1984;39:147-58.

[13] Bu C, Leckner B, Chen X, Gómez-Barea A, Liu D, Pallarès D. Devolatilization of a single fuel particle in a fluidized bed under oxy-combustion conditions. Part B: Modeling and comparison with measurements. Combust Flame 2015;162:809-18.

[14] Alves SS, Figueiredo JL. A model for pyrolysis of wet wood. Chem Eng Sci 1989;44:2861-9.

[15] Babu B V., Chaurasia AS. Modeling for pyrolysis of solid particle: Kinetics and heat transfer effects. Energy Convers Manag 2003;44:2251-75.

[16] Huang QX, Wang RP, Li WJ, Tang YJ, Chi Y, Yan JH. Modeling and Experimental Studies of the Effects of Volume Shrinkage on the Pyrolysis of Waste Wood Sphere. Energy \& Fuels 2014;28:6398-406.

[17] Gronli MG, Melaaen MC. Mathematical model for wood pyrolysis - Comparison of experimental measurements with model predictions. Energy \& Fuels 2000;14:791-800.

[18] Haseli Y, van Oijen JA, de Goey LPH. Numerical study of the conversion time of single pyrolyzing biomass particles at high heating conditions. Chem Eng J 2011;169:299-312.

[19] Navarrete Cereijo G, Curto-Risso P, Bizzo WA. Simplified model and simulation of biomass particle suspension combustion in one-dimensional flow applied to bagasse boilers. Biomass and Bioenergy 2017;99:38-48.

[20] Remacha MP, Jiménez S, Ballester J. Devolatilization of millimeter-sized biomass particles at high temperatures and heating rates. Part 2: Modeling and validation for thermally-thin and thick regimes. Fuel 2018;234:707-22.

[21] Rapagnà S, Mazziotti di Celso G. Devolatilization of wood particles in a hot fluidized bed: Product yields and conversion rates. Biomass and Bioenergy 2008;32:1123-9.

[22] Gaston KR, Jarvis MW, Pepiot P, Smith KM, Frederick WJ, Nimlos MR. Biomass Pyrolysis and Gasification of Varying Particle Sizes in a Fluidized-Bed Reactor. Energy Fuels 2011;25:374757.

[23] Di Blasi C, Branca C. Temperatures of wood particles in a hot sand bed fluidized by nitrogen. Energy and Fuels 2003;17:247-54.

[24] De Diego LF, García-Labiano F, Abad A, Gayán P, Adanez J. Modeling of the Devolatilization of Nonspherical Wet Pine Wood Particles in Fluidized Beds. Ind Eng Chem Res 2002;41:364250.

[25] De Diego LF, García-Labiano F, Abad A, Gayán P, Adanez J. Effect of moisture content on devolatilization times of pine wood particles in a fluidized bed. Energy Fuels 2003;17:285-90.

[26] Luo H, Wu H, Lin W, Dam-Johansen K. Heat transfer corrected isothermal model for devolatilization of thermally-thick biomass particles, Stockholm,Sweden: Nordic Flame Days; 2017.

[27] Masche M, Puig-Arnavat M, Wadenbäck J, Clausen S, Jensen PA, Ahrenfeldt J, et al. Wood pellet milling tests in a suspension-fired power plant. Fuel Process Technol 2018;173:89-102.

[28] Tolvanen H, Keipi T, Raiko R. A study on raw, torrefied, and steam-exploded wood: Fine grinding, drop-tube reactor combustion tests in $\mathrm{N} 2 / \mathrm{O} 2$ and $\mathrm{CO} 2 / \mathrm{O} 2$ atmospheres, particle geometry analysis, and numerical kinetics modeling. Fuel 2016;176:153-64. 
[29] Bryden KM, Ragland KW, Rutland CJ. Modeling thermally thick pyrolysis of wood. Biomass Bioenergy 2002;22:41-53.

[30] Grønli MG. A theoretical and experimental study of the thermal degradation of biomass. Norwegian University of Science and Technology, 1996.

[31] Siau JF. Transport processes in wood. vol. 2. Springer Science \& Business Media; 2012.

[32] Ranz WE, Marshall WR. Evaporation from drops - Part 1. Chem Eng Prog 1952;48:141-8.

[33] Bryden KM, Hagge MJ. Modeling the combined impact of moisture and char shrinkage on the pyrolysis of a biomass particle. Fuel 2003;82:1633-44.

[34] Koufopanos CA, Papayannakos N, Maschio G, Lucchesi A. Modelling of the pyrolysis of biomass particles. Studies on kinetics, thermal and heat transfer effects. Can J Chem Eng 1991;69:907-15.

[35] Lee CK, Chaiken RF, Singer JM. Charring pyrolysis of wood in fires by laser simulation. Symp Combust 1977;16:1459-70.

[36] Di Blasi C. Heat, momentum and mass transport through a shrinking biomass particle exposed to thermal radiation. Chem Eng Sci 1996;51:1121-32.

[37] Babu B V., Chaurasia AS. Heat transfer and kinetics in the pyrolysis of shrinking biomass particle. Chem Eng Sci 2004;59:1999-2012.

[38] Ramires ML V, Nieto de Castro CA, Nagasaka Y, Nagashima A, Assael MJ, Wakeham WA. Standard reference data for the thermal conductivity of water. J Phys Chem Ref Data 1995;24:1377-81.

[39] Trubetskaya A. Fast pyrolysis of biomass at high temperatures. Technical University of Denmark, 2016.

[40] Merrick D. Mathematical models of the thermal decomposition of coal: 2. Specific heats and heats of reaction. Fuel 1983;62:540-6.

[41] Stanish MA, Schajer GS, Kayihan F. A mathematical model of drying for hygroscopic porous media. AIChE J 1986;32:1301-11.

[42] Lide DR, Haynes WM. CRC Handbook of Chemistry and Physics. Taylor \& Francis; 2009.

[43] Wagenaar BM, Prins W, van Swaaij WPM. Flash pyrolysis kinetics of pine wood. Fuel Process Technol 1993;36:291-8.

[44] Li T, Ku X, Løva T. CFD simulation of devolatilization of biomass with shrinkage effect. Energy Procedia 2017;105:505-10.

[45] Ström H, Thunman H. CFD simulations of biofuel bed conversion: A submodel for the drying and devolatilization of thermally thick wood particles. Combust Flame 2013;160:417-31.

[46] Fatehi H, Bai XS. A Comprehensive Mathematical Model for Biomass Combustion. Combust Sci Technol 2014;186:574-93.

[47] Silva V, Rouboa A. Combining a 2-D multiphase CFD model with a Response Surface Methodology to optimize the gasification of Portuguese biomasses. Energy Convers Manag 2015;99:28-40.

[48] Biswas AK, Umeki K. Simplification of devolatilization models for thermally-thick particles: Differences between wood logs and pellets. Chem Eng J 2015;274:181-91.

[49] Di Blasi C. Modeling chemical and physical processes of wood and biomass pyrolysis. Prog Energy Combust Sci 2008;34:47-90.

[50] Johansen JM, Gadsbøll R, Thomsen J, Jensen PA, Glarborg P, Paul EK, et al. Devolatilization kinetics of woody biomass at short residence times and high heating rates and peak temperatures. 
640

641

642

643

644

645

646

647

Appl Energy 2016;162:245-56.

[51] Roberts AF, Clough G. Thermal decomposition of wood in an inert atmosphere. Symp Combust 1963;9:158-66.

[52] Roberts AF. A review of kinetics data for the pyrolysis of wood and related substances. Combust Flame 1970;14:261-72.

[53] Anca-Couce A, Sommersacher P, Scharler R. Online experiments and modelling with a detailed reaction scheme of single particle biomass pyrolysis. J Anal Appl Pyrolysis 2017;127:411-25. 